\title{
A Study on the Comparative Analysis of 2-MIB Treatment Characteristics and Optimization of Process Operation in 2-types of Advanced Water Treatment Plants in the Han River Water Supply System
}

\author{
Jong-II Park ${ }^{\dagger} \cdot$ Young Lee $\cdot$ Kyoung-A Jang $\cdot$ Keon-Hoi Kim $\cdot$ Tae-Hoon Lee $\cdot$ Sun-Wook Kim \\ Korea Water Resources Corporation (K-water)
}

(Received September 28, 2020; Revised December 1, 2020; Accepted December 14, 2020)

Objectives: In this study, through the results of the high-concentration 2-MIB (2-Methyl Isoborneol) treatment by two different types of advanced treatment plants (Post Peroxone $+\mathrm{GAC}, \mathrm{UV} / \mathrm{H}_{2} \mathrm{O}_{2}+\mathrm{GAC}$ F/A) which intake raw water from the same water intake facility, the 2-MIB removal characteristics by oxidation process of each WTPs (Water Treatment Plants) were compared and analyzed, and optimal operation methods were derived.

Methods: The 2-MIB removal rate was compared and analyzed according to each AOP (Advanced Oxidation Process) operating conditions (Post Peroxone+GAC of the G WTP and UV/ $\mathrm{H}_{2} \mathrm{O}_{2}+\mathrm{GAC}$ F/A of the I WTP). The optimal equations of chemical injection were derived through the correlation between the operating conditions of the AOP for each WTPs and 2-MIB removal rate. By analyzing the operating characteristics of each WTPs, the cost and unit price for optimal operation were calculated according to the 2-MIB concentration of raw water and water production. Optimal operating conditions were derived through the performance of oxidation facilities and chemical injection equations of each WTPs, and economical operating plans were reviewed through linked operation of 2 WTPs.

Results and Discussion: The 2-MIB removal rates for each WTPs were 70 100\% for the G WTP and 50 96\% for the I WTP. The operating conditions affecting the 2-MIB removal were $\left[\mathrm{O}_{3}\right.$ injection $\times$ contact time $], \mathrm{H}_{2} \mathrm{O}_{2} / \mathrm{O}_{3}$ for Post Peroxone of the G WTP, and [UV dose $\times \mathrm{H}_{2} \mathrm{O}_{2}$ injection] for UV/ $\mathrm{H}_{2} \mathrm{O}_{2}$ of the I WTP. As a result of comparing the operating cost(electric power cost + chemical cost) of each WTPs, I WTP was $6.6 \sim 24.3 \mathrm{KRW} / \mathrm{m}^{3}$ higher than G WTP. It is considered to be because the $\mathrm{H}_{2} \mathrm{O}_{2}$ injection was 11 43 times for $\mathrm{UV} / \mathrm{H}_{2} \mathrm{O}_{2}$ than Post Peroxone. Optimal operating conditions could be derived through the performance evaluation of each oxidation facilities and chemical injection equations of each WTPs. The G WTP and the I WTP are equipped with pipe line for linked operation in the water supply pipes, so the water production for each WTPs can be distributed. In the case of the same water production, it was confirmed that the unit price can be reduced when the water production ratio of the G WTP is increased. Because the decrease in cost of the I WTP is higher than the increase in cost of the G WTP.

Conclusions: It was confirmed that both Post Peroxone+GAC of G WTP and UV/ $\mathrm{H}_{2} \mathrm{O}_{2}+\mathrm{GAC}$ F/A of I WTP were effective in 2-MIB treatment. As for the operating cost, it was analyzed that $\mathrm{UV} / \mathrm{H}_{2} \mathrm{O}_{2}$ had higher unit pice than Post Peroxone because of the large amount of $\mathrm{H}_{2} \mathrm{O}_{2}$ injection. Considering the 2-MIB removal rate and operating cost of each WTPs, it was possible to derive the optimal operating conditions for each WTPs and a linked operation plan.

Keywords : 2-MIB, Peroxone, Ozone, UV, AOP

The Korean text of this paper can be translated into multiple languages on the website of http:/jksee.or.kr through Google Translator. 


\title{
연구논문
}

\section{한강수계 2개 유형 고도처리 정수장의 2-MIB 처리 특성 비교 분석 및 공정 운영 최적화 연구}

\author{
박종일 ${ }^{\dagger} \cdot$ 이 영·장경아·김건회·이태훈 · 김선욱
}

한국수자원공사

목적: 본 연구에서는 동일한 취수장에서 원수를 취수하는 상이한 2개 유형 고도처리 정수장(Post Peroxone+GAC, $\mathrm{UV} / \mathrm{H}_{2} \mathrm{O}_{2}+\mathrm{GAC} \mathrm{F} / \mathrm{A}$ )의 고농도 2-MIB (2-Methyl Isoborneol) 대응 결과를 통하여 각 정수장의 산화 공정별 2-MIB 제거 특성을 비교 분석하고 최적 운영 방안을 도출하였다.

방법 : Post Peroxone+GAC (Granular Activated Carbon)가 도입된 G정수장과 $\mathrm{UV} / \mathrm{H}_{2} \mathrm{O}_{2}+\mathrm{GAC}$ F/A가 도입된 I정수장 의 고도산화공정(Advanced Oxidation Process, AOP) 운영 조건에 따른 2-MIB 처리율을 비교 분석하였다. 정수장별 $\mathrm{AOP}$ 운영 조건과 2-MIB 제거율의 상관관계를 통하여 최적 약품 주입률 산정식을 도출하고, 각 정수장별 공정 운 영 특성을 분석하여 원수 2-MIB 농도 및 용수생산량에 따른 최적 운영 시의 소요 비용과 원단위를 산정하였다. 각 정수장 산화 설비의 성능 평가 결과 및 약품 주입률 산정식을 통해 최적 운영 조건을 도출하였으며, 연계운영을 통한 경제적인 대응 방안을 검토하였다.

결과 및 토의: 정수장별 2-MIB 제거율은 $\mathrm{G}$ 정수장 $70 ~ 100 \%$, I정수장 50 96\%로 나타났다. 2-MIB 제거에 영향을 미치는 운영 조건은 Post Peroxone은 [ $\mathrm{O}_{3}$ 주입률 $\times$ 접촉시간]과 $\mathrm{H}_{2} \mathrm{O}_{2} / \mathrm{O}_{3}, \mathrm{UV} / \mathrm{H}_{2} \mathrm{O}_{2}$ 는 [UV 조사량 $\times \mathrm{H}_{2} \mathrm{O}_{2}$ 주입률] 이었다. 각 정수장의 운영비(전력비+약품 구매비) 원단위 비교 결과, I정수장이 $\mathrm{G}$ 정수장보다 6.6 24.3원 $/ \mathrm{m}^{3}$ 높았다. 이는 UV/ $\mathrm{H}_{2} \mathrm{O}_{2}$ 의 $\mathrm{H}_{2} \mathrm{O}_{2}$ 주입률이 Post Peroxone 대비 11 43배였기 때문인 것으로 사료된다. 각 정수장 산화 설비의 성능평가 결과 및 약품 주입률 산정식을 통해 최적 운영 조건을 도출할 수 있었다. G정수장과 I정수장의 송수관로 에는 연계운영을 위한 배관이 설치되어 있어 각 정수장별 용수생산량의 배분이 가능하다. 용수생산량이 동일할 경 우, $\mathrm{G}$ 정수장의 용수생산비율을 높일 때 $\mathrm{G}$ 정수장의 원단위 상승비용보다 I정수장의 원단위 감소비용이 더 크기 때 문에 원단위 절감이 가능함을 확인할 수 있었다.

결론: G정수장의 Post Peroxone $+\mathrm{GAC}$, I정수장의 $\mathrm{UV} / \mathrm{H}_{2} \mathrm{O}_{2}+\mathrm{GAC}$ F/A 모두 2-MIB 처리에 효과적임을 확인할 수 있었다. 운영비용의 경우, $\mathrm{UV} / \mathrm{H}_{2} \mathrm{O}_{2}$ 가 $\mathrm{H}_{2} \mathrm{O}_{2}$ 의 주입량이 많아 Post Peroxone보다 원단위가 높은 것으로 분석되었다. 각 정수장의 공정별 2-MIB 처리율과 운영비를 고려하여, 정수장별 최적 운영 조건과 연계운영 방안을 도출할 수 있었다.

주제어: 2-MIB, Peroxone, 오존, UV, AOP

\section{1. 서론}

최근 기후변화로 인해 한강수계에 남조류가 이상 증식하여 상수원인 팔당호에 고농도의 이취미 물질이 발생하는 사례 가 반복되고 있다. ${ }^{1,2)}$ 이취미를 유발하는 대표적인 물질인 Geosmin과 2-MIB는 주로 남조류(Anabaena, Aphanozomenon, Lyngbya, Oscillatoria, Phornmidium, Planktonthrix, Pseudanabaena 등)에 의해 발생되는 것으로 보고되고 있다. ${ }^{3-8)} \mathrm{Geosmin}$ 과 2-MIB는 독성은 없으나, 극미량으로도 냄새와 맛을 유발할 수 있고 ${ }^{9)}$ 수계에 광범위하게 발생하면 수돗물 사용에 불쾌감을 발
생시킬 수 있다. 국내에서는 Geosmin과 2-MIB를 2009년에 먹는 물 감시항목으로 지정하였으며 기준 농도는 $20 \mathrm{ng} / \mathrm{L}$ 이하이다.

Geosmin과 2-MIB의 효과적인 처리를 위해 고도정수처리 시설이 도입되고 있다. 고도정수처리 시설은 일반정수처리 공정으로는 완전히 제거되지 않는 맛-냄새 물질, 미량유기 오염물질, 내염소성 병원성 미생물 등을 제거하기 위하여 설 치하는 시설을 의미하며(환경부 고도정수처리시설 도입 및 평가지침, 2013년), 2018년 기준 국내에 고도정수처리 공정 (막여과 포함)이 도입된 정수장은 개소수 기준 $14 \%$ (총 484 개 중 72 개), 시설용량 기준 $40 \%$ (27백만 $\mathrm{m}^{3} /$ 일 중 11 백만 $\mathrm{m}^{3} /$ 일 $)$ 
에 이른다(환경부 2018 상수도 통계, 2019년).

맛-냄새 물질 제거를 위한 고도정수처리 공정은 일반적으로 산화와 흡착으로 구성된다. 산화 공정 중 $\mathrm{AOP}$ 는 상온·상압 하에서 높은 산화력을 가진 $\mathrm{OH} \cdot$ 을 발생시켜 맛·냄새 물질 등 난분해성 유기물을 효과적으로 처리할 수 있다. $\mathrm{AOP}$ 는 $\mathrm{OH} \cdot$ 을 발생시키는 방법에 따라 다양하게 분류될 수 있으며, 국내 정수장에는 Peroxone $\left(\mathrm{O}_{3} / \mathrm{H}_{2} \mathrm{O}_{2}\right)$ 과 $\mathrm{UV} / \mathrm{H}_{2} \mathrm{O}_{2}$ 가 도입·운 영 중이다.

국내 대부분의 고도처리 정수장에 도입된 $\mathrm{O}_{3}$ 은 원생동물인 Giardia에 대한 살균 효율이 높고, 산화력이 강해 맛-냄새 물 질 등 유기물을 효과적으로 제거할 수 있다. 또한 $\mathrm{H}_{2} \mathrm{O}_{2}$ 와 병행 하여 AOP인 Peroxone으로 운영함으로써 ${ }^{10)}$ 맛·냄새 물질 ${ }^{11,12)}$ 은 물론 다양한 유기물질 ${ }^{13,14)}$ 의 처리효율을 제고할 수 있다. 그러나 잔류 용존 $\mathrm{O}_{3}$ 으로 인해 $\mathrm{GAC}$ 등의 후속 공정 시설물에 $\mathrm{O}_{3}$ 가스가 휘발-농축되어 작업 안전성을 저해할 수 있다. ${ }^{15,16)}$

$\mathrm{UV}$ 는 원생동물인 Giardia는 물론 Cryptosporidium 에 대한 살균 효율이 높아 ${ }^{17)}$ 유럽 및 북미 지역에서 소독공정으로 활용된다. ${ }^{18)}$ 또한 $\mathrm{UV}$ 는 $\mathrm{O}_{3}$ 산화나 Peroxone보다 NDMA (N-Nitrosodimethylamine) 처리 효율이 양호하여 ${ }^{19,20)}$, 미국 California의 Orange county 수도국 Water Factory 21 ${ }^{21)}$, San Gabriel Valley 정수장 등에서는 UV 공정을 도입하여 운영하 고 있다. $\mathrm{H}_{2} \mathrm{O}_{2}$ 주입 후 UV를 조사하면 $\mathrm{OH}$-이 발생되어 AOP 로 활용할 수 있다. $\mathrm{UV} / \mathrm{H}_{2} \mathrm{O}_{2}$ 역시 맛.냄새 물질 ${ }^{22,23)}$ 은 물론 다양한 유기물질 ${ }^{24)}$ 을 처리할 수 있다. $\mathrm{UV} / \mathrm{H}_{2} \mathrm{O}_{2}$ 는 $\mathrm{O}_{3}$ 공정 대비 소요 부지 면적이 작고 설비가 간단하며 $\mathrm{O}_{3}$ 가스에 의한 작업 안전성 저해 문제가 없는 장점이 있다. 그러나 $\mathrm{O}_{3}$ 기반
공정에 비해 AOP 반응 유도를 위한 $\mathrm{H}_{2} \mathrm{O}_{2}$ 의 주입률이 높아 운영비가 높은 단점이 있다. ${ }^{25} \mathrm{UV} / \mathrm{H}_{2} \mathrm{O}_{2}$ 는 현재 국내 2 개 정수 장에서 운영 중이며, 일부 정수장에서 도입을 검토하고 있다. 2015년 이후 한강수계에서는 이취미 물질 중 상대적으로 처 리가 더 어려운 2-MIB ${ }^{26,27)}$ 의 농도 및 발생일수가 증가하는 경 향을 나타내고 있다. 정수장에서는 2-MIB를 효과적으로 처리 하여 수돗물의 품질을 유지해야 하며, 이를 위해서는 고도정수 처리 공정의 효율적인 운영이 필요하다. 또한, 정수장에 고도정 수처리 공정 도입 시 적용 공법을 선정하기 위해서는 실공정에 서의 운영 사례를 비교 분석할 필요가 있다. 본 연구에서는 동일한 취수원에서 원수를 취수하는 상이한 2개 유형의 고도처 리 정수장(Post Peroxone $\left.+\mathrm{GAC}, \mathrm{UV} / \mathrm{H}_{2} \mathrm{O}_{2}+\mathrm{GAC} \mathrm{F} / \mathrm{A}\right)$ 의 고농도 2-MIB 대응 결과를 통하여 각 정수장의 산화공정별 2-MIB 제거 특성을 비교 분석하고 최적 운영 방안을 도출하였다.

\section{2. 시설 현황 및 연구 방법}

\section{1. 시설 현황}

\subsection{1. 정수장 시설 현황}

본 연구에서는 동일한 취수원(한강수계 $\mathrm{P} 1$ 취수장)에서 원 수를 취수하며 정수장까지의 도달시간이 비슷하여(도수관로 길이 약 $53 \mathrm{~km}$, 도달시간 약 20시간) 착수정에서의 수질이 유사하지만, 상이한 고도정수처리 공정이 적용된 경기도 고양 시 소재의 2 개 정수장 $(\mathrm{G}$ 정수장, I정수장)을 대상으로 하였다. 각 정수장의 정수처리 공정도를 Fig. 1 에 나타내었다.

$\mathrm{G}$ 정수장의 시설용량은 $350,000 \mathrm{~m}^{3} /$ 일로, 현재 운영 가능한

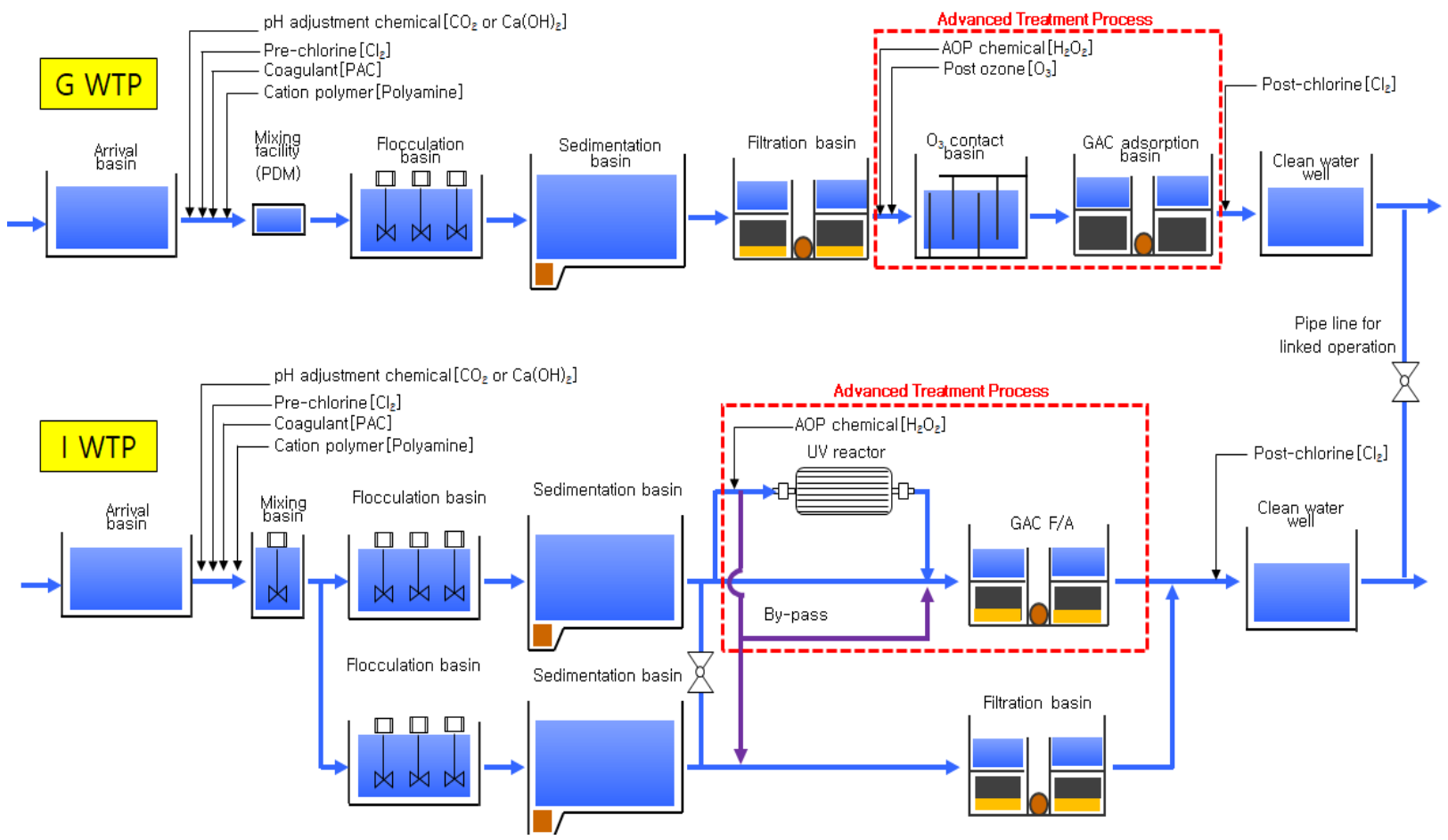

Fig. 1. Schematic diagram of each WTP process. 
Table 1. Detailed information on advanced treatment process in G WTP.

\begin{tabular}{|c|c|c|}
\hline \multicolumn{2}{|c|}{ Classification } & Contents \\
\hline \multirow{3}{*}{$\mathrm{O}_{3}$ generation and injection } & Generation type & Corona discharge \\
\hline & $\mathrm{O}_{3}$ generation capacity & $10.5 \mathrm{~kg} / \mathrm{h} \times 2$ ea \\
\hline & Injection type & Side stream \\
\hline \multirow{3}{*}{$\mathrm{O}_{3}$ contact basin } & Specification of basin & B $18.0 \mathrm{~m} \times \mathrm{L} 18.2 \mathrm{~m} \times \mathrm{H} 6.0 \mathrm{~m}$ \\
\hline & Quantity & $2 \mathrm{ea}$ \\
\hline & Total volume & $3,931 \mathrm{~m}^{3}$ \\
\hline \multirow{2}{*}{$\mathrm{O}_{3}$ monitoring } & Dissolved $\mathrm{O}_{3}$ & Measuring at 3 points in $\mathrm{O}_{3}$ contanct basin \\
\hline & Atmospheric $\mathrm{O}_{3}$ & Measuring in GAC adsorption basin \\
\hline \multirow{3}{*}{$\mathrm{H}_{2} \mathrm{O}_{2}$ injection } & Pump type & Tube pump \\
\hline & Pump capacity & $500 \mathrm{~mL} / \mathrm{min} / \mathrm{ea} \times 2 \mathrm{ea}$ \\
\hline & Mixing type & Nozzle diffuser \\
\hline \multirow{2}{*}{ Off-gas $\mathrm{O}_{3}$ destroyer } & $\mathrm{O}_{3}$ contanct basin & Pyrolysis \\
\hline & GAC adsorption basin & Catalytic oxidation \\
\hline \multirow{4}{*}{ GAC } & Effective diameter & $0.65 \mathrm{~mm}$ \\
\hline & Depth of GAC & $2.4 \mathrm{~m}$ \\
\hline & Specification of basin & B $5.0 \mathrm{~m} \times \mathrm{L} 15.0 \mathrm{~m}\left(75 \mathrm{~m}^{2} / \mathrm{ea}\right)$ \\
\hline & Quantity & 12 ea \\
\hline
\end{tabular}

용량은 $210,000 \mathrm{~m}^{3} /$ 일 $\left(140,000 \mathrm{~m}^{3} /\right.$ 일은 장래 도입 예정)이다. 현재 착수정, $\mathrm{O}_{3}$ 접촉조, 정수지는 시설용량 $\left(350,000 \mathrm{~m}^{3} /\right.$ 일) 기준으로 설치 완료되었으며, 기타 공정(응집, 침전, 여과, $\mathrm{O}_{3}$ 발생, $\mathrm{GAC}$ 흡착)의 설비는 장래분 도입 시 추가될 예정이다. 고도정수처리 공정은 산화공정인 Post $\mathrm{O}_{3}$ 과 흡착공정인 $\mathrm{GAC}$ 가 도입되었으며, 2017년에 Post Peroxone $\left(\mathrm{O}_{3} / \mathrm{H}_{2} \mathrm{O}_{2}\right)$ 을 적용 할 수 있도록 설비를 개선하였다. $\mathrm{G}$ 정수장에서는 용존 잔류 $\mathrm{O}_{3}$ 이 후속 공정인 $\mathrm{GAC}$ 흡착지 건물 내에 휘발 및 농축되어 작업 안전성을 저해할 우려가 있다. 이 경우 잔류 $\mathrm{O}_{3}$ 제거 (quenching) 공정을 운영할 필요가 있다. $\mathrm{G}$ 정수장에는 $\mathrm{H}_{2} \mathrm{O}_{2}$ 또는 $\mathrm{Na}_{2} \mathrm{~S}_{2} \mathrm{O}_{3}$ 를 활용한 quenching 설비가 적용되어 있으나 최근 수돗물 유충 사태로 인해 $\mathrm{GAC}$ 시설의 완전 밀폐가 검토 되고 있는 바, 본 연구에서는 quenching 공정 운영은 고려하지 않았다.

I정수장의 시설용량은 $250,000 \mathrm{~m}^{3} /$ 일(1단계 $150,000 \mathrm{~m}^{3} /$ 일. 2 단계 $100,000 \mathrm{~m}^{3} /$ 일)로, 최초에는 표준정수처리 공정만 도입 되었다. 맛-냄새 물질 대응을 위한 고도정수처리 공정 도입 시, 산화 공정은 $\mathrm{Pre}_{3}$ 산화(Pre Peroxone으로 개선 가능)와 $\mathrm{UV} / \mathrm{H}_{2} \mathrm{O}_{2}$ 의 2 개 공정을 비교하였다. 비교 결과, 운영비용은 더 고가이나 공사비용이 더 저렴하여 20년 운영 시의 종합적 인 경제성이 우수하고, 신규 공정 운영을 통한 기술력 확보가 가능한 $\mathrm{UV} / \mathrm{H}_{2} \mathrm{O}_{2}$ 를 선정하였다. 흡착 공정은 부지의 추가 확 보가 어려워 $\mathrm{GAC}$ 흡착지를 신설하지 않고 기존의 여과지를 GAC F/A (Filtration/Adsorption)로 개량하였다. 고도정수처리 공정은 2016년에 1단계 시설에 도입되었으며, 2단계 시설에 는 2022년까지 도입을 완료할 예정이다.

각 정수장의 송수관로에는 연계 운영을 위한 관로 및 밸브가
설치되어 있다. 이를 통해 각 정수장에서 생산된 수돗물은 타 정수장의 급수 구역으로 공급할 수 있다.

\subsection{2. 고도정수처리 설비 현황}

G정수장의 고도정수처리 공정 현황을 Table 1에 나타내었다. $\mathrm{O}_{3}$ 은 코로나 방전 방식 발생기로 생산되어(대당 최대 발생량 $10.5 \mathrm{~kg} / \mathrm{h}, 2$ 대) side-stream 방식으로 주입된다. $\mathrm{O}_{3}$ 접촉지는 2 개지로 구성되어 있으며, 총 용량은 $3,931 \mathrm{~m}^{3}$ 이다. Post Peroxone 운영 시에는 $\mathrm{O}_{3}$ 주입 전단 지점에 $\mathrm{H}_{2} \mathrm{O}_{2}$ 를 tube pump 를 통하여 주입하며 nozzle diffuser를 통하여 혼화된다. 용존 $\mathrm{O}_{3}$ 은 $\mathrm{O}_{3}$ 접촉지 내 3 개 지점, 대기 $\mathrm{O}_{3}$ 농도는 $\mathrm{GAC}$ 흡착지 실내에서 실시간으로 측정된다. Off-gas $\mathrm{O}_{3}$ 파괴기는 $\mathrm{O}_{3}$ 접촉 조에는 열분해식, $\mathrm{GAC}$ 흡착지에는 촉매산화식이 적용되었 다. ${ }^{10} \mathrm{O}_{3}$ 와 $\mathrm{H}_{2} \mathrm{O}_{2}$ 주입 및 접촉지 모식도를 Fig.2에 나타내었다.

$\mathrm{GAC}$ 는 석탄계로 유효경 $0.65 \mathrm{~mm}$ 이며, 흡착지의 포설심도 는 $2.4 \mathrm{~m}, \mathrm{EBCT}$ (Empty Bed Contact Time)는 14.8분으로 총 12 개지가 설치되어 있다.

장래분은 2024년 준공 예정으로, $\mathrm{O}_{3}$ 발생기 1기와 $\mathrm{GAC}$ 흡 착지 8 개지가 증설될 예정이다.

I정수장의 고도정수처리 공정 현황을 Table 2에 나타내었다. UV reactor는 2기가 설치되어 있으며, 각 reactor는 6개의 섹션으로 구성되어 있다. UV 램프는 저압고출력(LPHO) 타입 으로 1 개 섹션당 16 개(reactor당 총 96개)가 설치되어 있다. UV 가동전력 범위는 30 100\%로 탄력적인 운영이 가능하다. $\mathrm{UV} / \mathrm{H}_{2} \mathrm{O}_{2}$ 반응을 위한 $\mathrm{H}_{2} \mathrm{O}_{2}$ 는 UV 반응조 전단에 tube pump를 통하여 주입하며 nozzle diffuser를 통하여 혼화된다. ${ }^{28)} \mathrm{UV}$ reactor 모식도를 Fig.3에 나타내었다. 


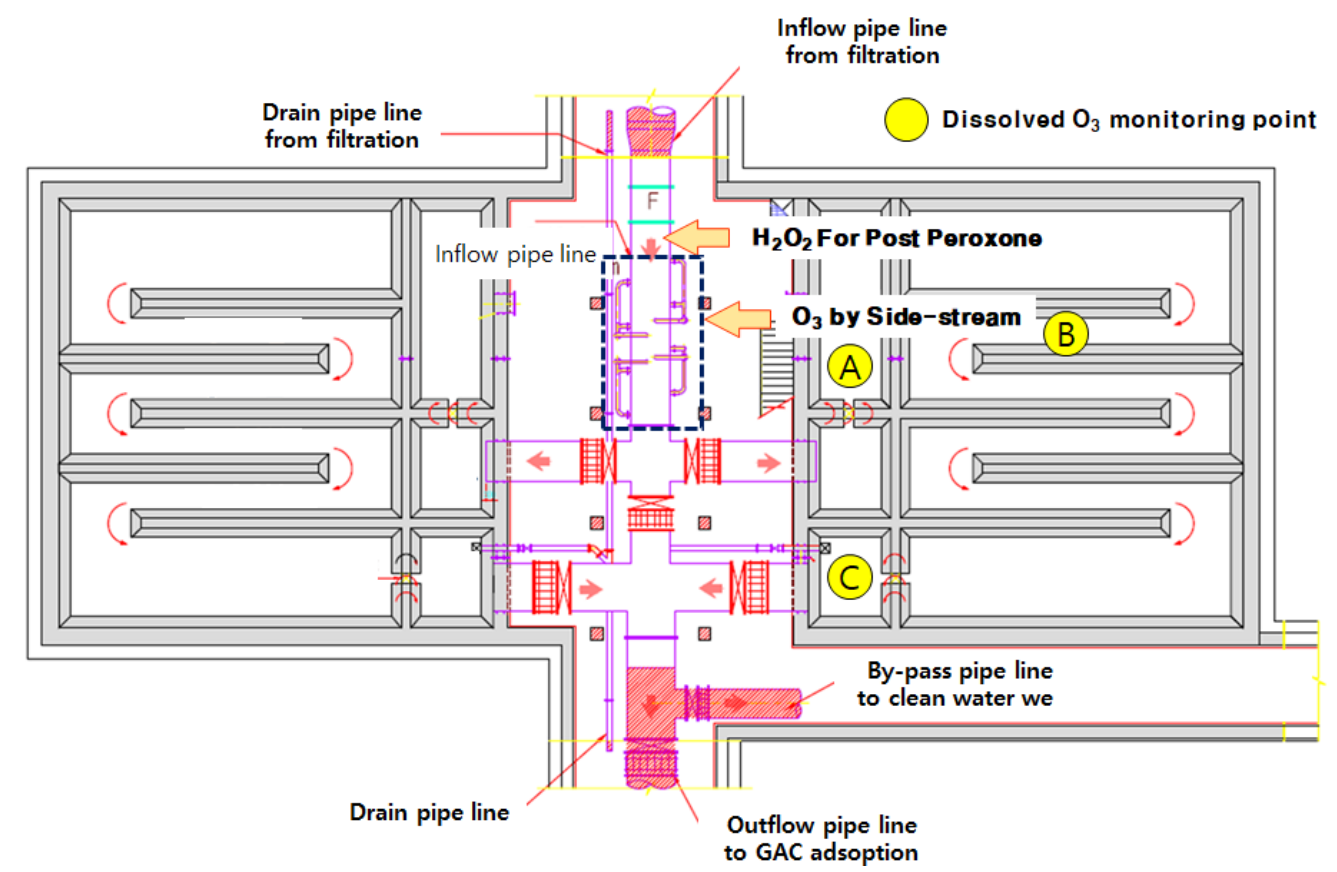

Fig. 2. Schematic diagram of chemicals $\left(\mathrm{O}_{3}, \mathrm{H}_{2} \mathrm{O}_{2}\right)$ injection and contact basin.

Table 2. Detailed information on advanced treatment process in I WTP.

\begin{tabular}{|c|c|c|}
\hline \multicolumn{2}{|c|}{ Classification } & Contents \\
\hline \multirow{4}{*}{$\begin{array}{l}\text { UV } \\
\text { reactor }\end{array}$} & Specification of reactor & B $1.876 \mathrm{~m} \times \mathrm{L} 8.230 \mathrm{~m} \times \mathrm{H} 1.994 \mathrm{~m}$ \\
\hline & Quantity & 2 ea \\
\hline & UV contact volume & $14.1 \mathrm{~m}^{3} /$ reactor \\
\hline & Flow per reactor & $78,750 \mathrm{~m}^{3} /$ day/reactor \\
\hline \multirow{4}{*}{$\begin{array}{l}\text { UV } \\
\text { lamp }\end{array}$} & Input power per lamp & 1.0 kW (@253.7 nm) \\
\hline & Lamp type & Low-Pressure High-Output \\
\hline & Number of lamps & 96 ea per reactor ( 16 ea/section $\times 6$ section) \\
\hline & Power level & $30 \%$ to $100 \%$ \\
\hline \multirow{3}{*}{$\begin{array}{c}\mathrm{H}_{2} \mathrm{O}_{2} \\
\text { injection and storage }\end{array}$} & Pump type & Tube pump \\
\hline & Pump capacity & $1,000 \mathrm{~mL} / \mathrm{min} / \mathrm{ea} \times 3$ ea \\
\hline & Storage tank & $10 \mathrm{~m}^{3} /$ ea $\times 2$ ea, $30 \mathrm{~m}^{3} /$ ea $\times 2$ ea \\
\hline \multirow{4}{*}{ GAC F/A } & Effective diameter & $1.1 \mathrm{~mm}$ \\
\hline & Depth of GAC & $1.7 \mathrm{~m}$ \\
\hline & Specification of basin & B $4.85 \mathrm{~m} \times \mathrm{L} 11.5 \mathrm{~m} \times 2$ cells $\left(111.55 \mathrm{~m}^{2} / \mathrm{ea}\right)$ \\
\hline & Quantity & 8 ea \\
\hline
\end{tabular}

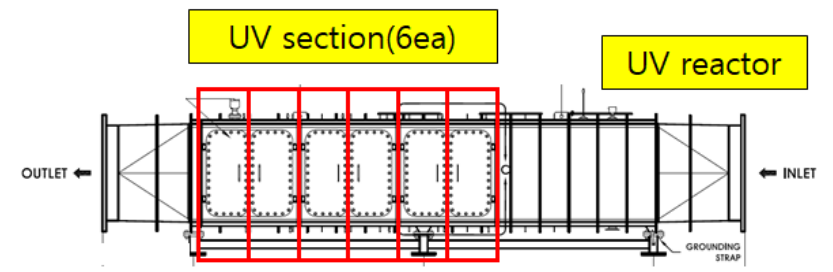

Fig. 3. Schematic diagram of UV reactor.

$\mathrm{GAC}$ 는 석탄계로, 유효경 $1.1 \mathrm{~mm}$ 이며, $\mathrm{F} / \mathrm{A}$ 지의 포설심도는 $1.7 \mathrm{~m}, \mathrm{EBCT}$ 는 14.6 분으로 총 8 개지가 설치되어 있다.
2단계 고도공정 도입시 UV reactor 2기와 $\mathrm{H}_{2} \mathrm{O}_{2}$ 주입 펌프 및 저장 탱크, F/A지 6개지가 증설될 예정이다.

\section{2. 연구방법}

\subsection{1. 맛·냄새 물질(Geosmin, 2-MIB) 모니터링}

맛-냄새 물질 발생 시 정수장에서 적기에 적절히 대응하기 위하여 취수원수와 정수의 Geosmin 및 2-MIB 농도를 주기적 으로 모니터링하고 있다. Geosmin 및 2-MIB 농도는 평상시에 월 1 회 분석하며, 취수원 조류 개체수 증가시 또는 Geosmin 및 2-MIB 농도 상승 시에는 분석주기를 주 1회 일 2회로 조정 


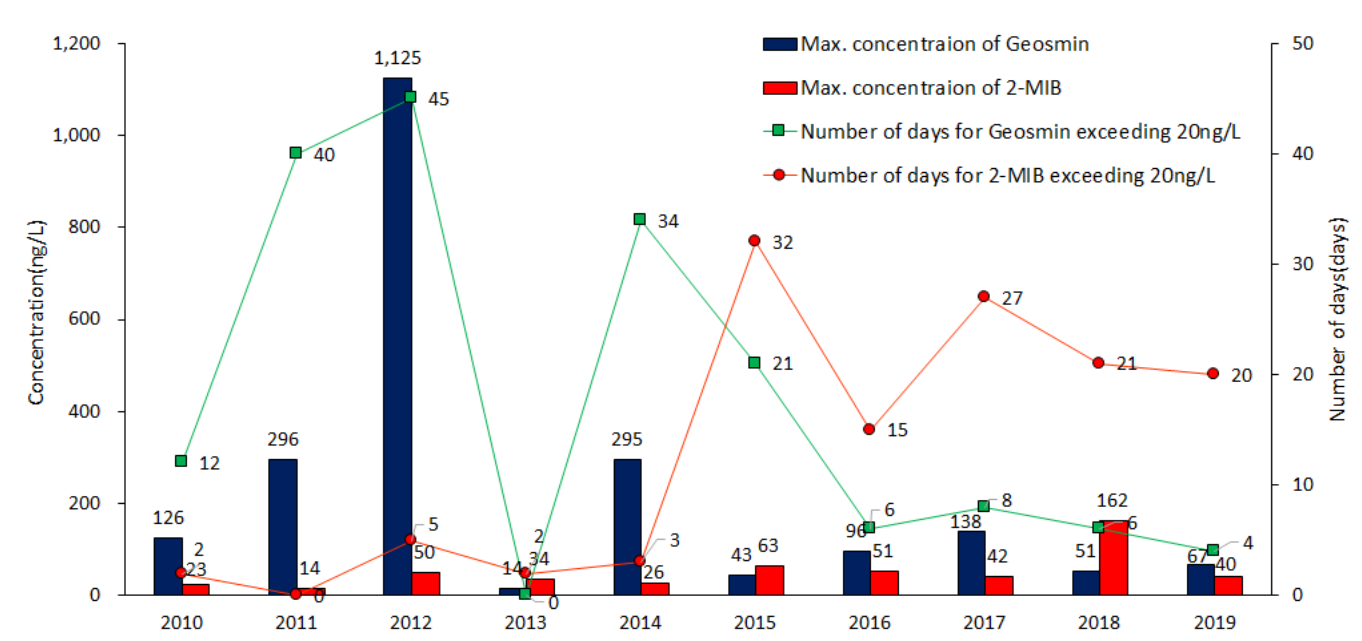

Fig. 4. Geosmin and 2-MIB concentraion at P1 intake facility in Han river.

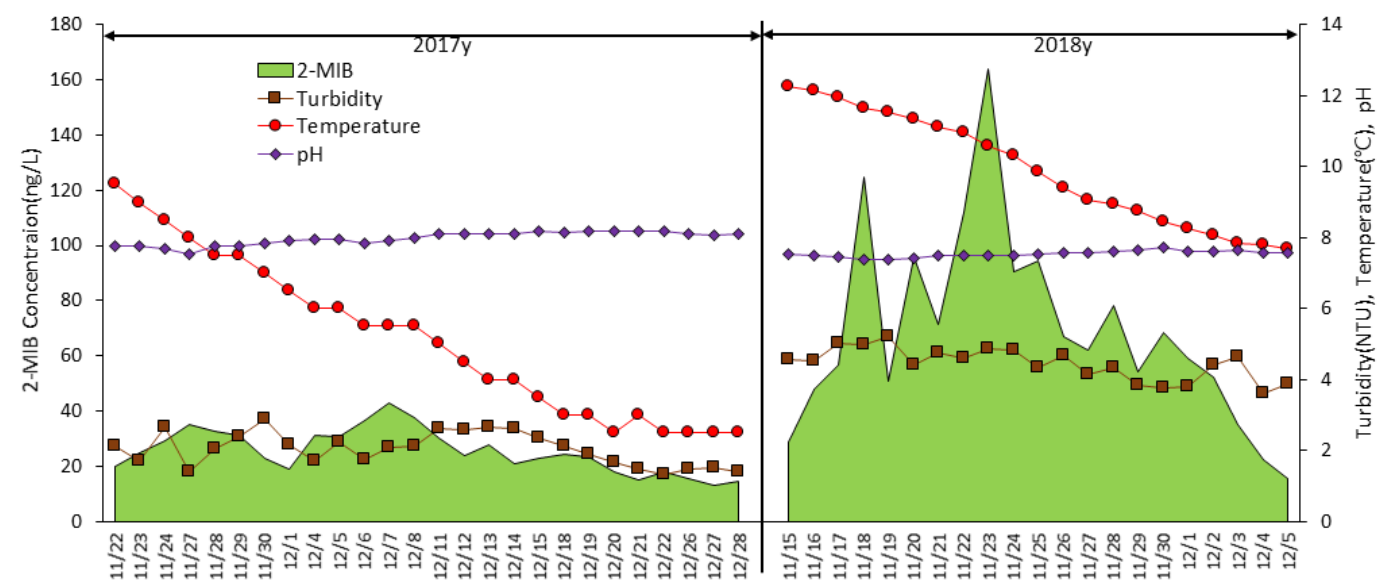

Fig. 5. Raw water quality at 2017 \& 2018 winter season.

한다. Geosmin 및 2-MIB 농도는 먹는물 수질 감시항목 시험방 법에 의거하여 분석하였다.

\subsubsection{2-MIB 제거 특성 비교 분석}

2017년과 2018년 동절기에 P1 취수원의 2-MIB가 먹는물 감시항목기준 $(20 \mathrm{ng} / \mathrm{L})$ 을 초과하여 고농도로 발생함에 따라 (최대 $162 \mathrm{ng} / \mathrm{L}$ ) G정수장과 I정수장에서는 고도정수처리 공정 을 강화 운영하여 대응하였다. 본 연구에서는 해당 기간의 정수장 및 공정별로 운영 조건에 따른 2-MIB 제거율과 소요비 용 및 원단위를 분석하였다. 또한, 안정적인 2-MIB 처리를 위한 정수장별 산화공정의 최적 운영 조건 도출을 위하여 운 영 조건 $\left(\mathrm{O}_{3}\right.$ 주입률 및 접촉시간, $\mathrm{UV}$ 조사량, $\mathrm{H}_{2} \mathrm{O}_{2}$ 주입률 등)과 2-MIB 제거율의 상관관계를 분석하였다.

\subsection{3. 최적 운영조건 도출}

각 정수장 산화 설비의 성능평가 및 약품 주입률 산정식을 통해 최적 운영 조건을 도출하고, 해당 조건 시의 소요 비용 및 원단위를 산정하였다. 또한, $\mathrm{G}$ 정수장과 I정수장의 연계운 영을 통한 경제적인 대응 방안을 검토하였다.

\section{3. 결과 및 고찰}

\section{1. 원수 수질 모니터링 결과}

2010년대(2010년 2019년) 한강수계 P1취수장 맛·냄새 물질 발생 현황을 Fig.4에 나타내었다.

Geosmin은 2012년에 연간 최고 농도 $1,125 \mathrm{ng} / \mathrm{L}$, 먹는물 감시항목 기준 $(20 \mathrm{ng} / \mathrm{L}$ 이하) 이상 발생일수 45 일을 기록하였 다. 2-MIB는 2015년 최장 발생일수(32일), 2018년 연간 최고 농도 $(162 \mathrm{ng} / \mathrm{L})$ 를 기록하였다. 2018년도 고농도 2-MIB 발생 시에는 취수원 상류댐 비상방류(소양강댐 $200 \mathrm{~m}^{3} / \mathrm{sec}$, 춘천댐 $\left.30 \mathrm{~m}^{3} / \mathrm{sec}, 11 / 28 \sim 12 / 10\right)$ 로 맛·냄새 물질의 희석 및 체류시간 저감을 통해 $20 \mathrm{ng} / \mathrm{L}$ 이상 발생일수를 단축할 수 있었다.

2017년과 2018년 2-MIB 발생시의 G정수장 및 I정수장 원수 수질을 Fig. 5에 나타내었다.

최대 2-MIB 농도는 2017년 $40 \mathrm{ng} / \mathrm{L}, 2018$ 년 $160 \mathrm{ng} / \mathrm{L}$ 를 초과하였다. 2018년에는 2017년보다 수온과 탁도는 높고 $\mathrm{pH}$ 는 낮은 경향을 보였다. 각 해당 기간 중 탁도와 $\mathrm{pH}$ 는 큰 변화 가 없었으나, 수온은 시간의 경과에 따라 낮아짐을 확인할 수 있었다. 


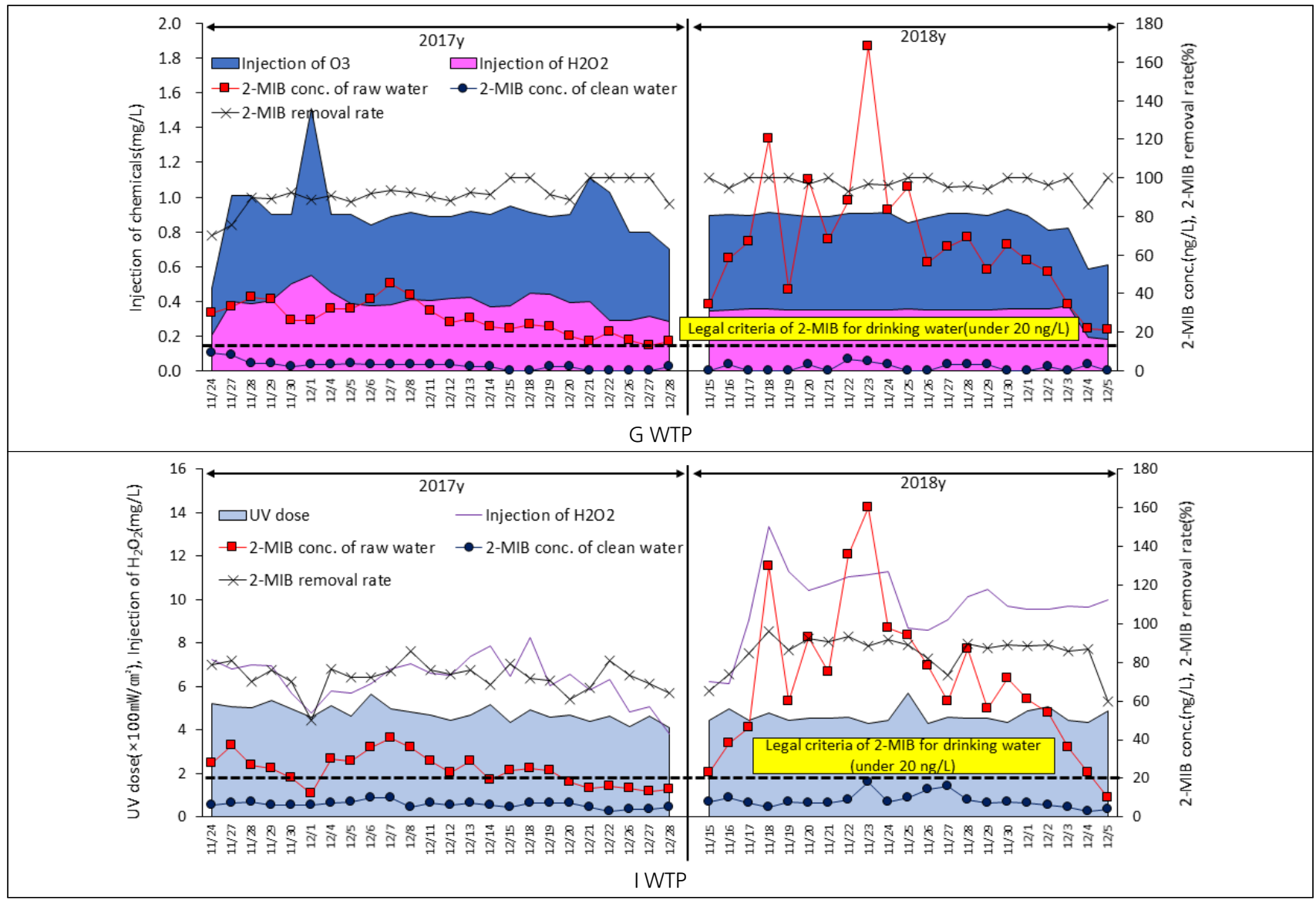

Fig. 6. 2-MIB treatment status of G WTP \& I WTP.

\section{2. 정수장 및 공정별 2-MIB 처리 결과}

$\mathrm{G}$ 정수장과 I정수장의 2017년과 2018년 2-MIB 대응 현황을

Fig. 6 에 나타내었다.

$\mathrm{G}$ 정수장(Post Peroxone+GAC)은 $\mathrm{O}_{3}$ 주입률 $0.5 \sim 1.6 \mathrm{mg} / \mathrm{L}$, $\mathrm{H}_{2} \mathrm{O}_{2}$ 주입률 $\left.0.2 \sim 0.5 \mathrm{mg} / \mathrm{L}_{(} \mathrm{H}_{2} \mathrm{O}_{2} / \mathrm{O}_{3}: 0.3 \sim 0.5\right)$ 로 운영하여 2-MIB를 70 100\%, I정수장 $\left(\mathrm{UV} / \mathrm{H}_{2} \mathrm{O}_{2}+\mathrm{GAC} \mathrm{F} / \mathrm{A}\right)$ 은 UV 조사 량 $413 \sim 569 \mathrm{~mJ} / \mathrm{cm}^{2}, \mathrm{H}_{2} \mathrm{O}_{2}$ 주입률 $4 \sim 13 \mathrm{mg} / \mathrm{L}$ 로 운영하여 2-MIB를 50 96\% 제거할 수 있었다.

두 정수장 모두 2-MIB의 먹는물 감시항목 기준 $(20 \mathrm{ng} / \mathrm{L}$ 이하)을 상시 만족할 수 있었다. 이는 각 정수장의 $\mathrm{AOP}$ 운영 을 통한 $\mathrm{OH}$-의 발생으로 효과적인 2-MIB 처리가 가능했기 때문인 것으로 사료된다.

2017년 고농도 2-MIB 유입 초기에, 고도처리 공정 운영조건 결정을 위해 분석한 공정수 중 2-MIB 농도 및 제거율을 Fig. 7에 나타내었다.

2-MIB는 고도정수처리 공정(Post Peroxone $+\mathrm{GAC}, \mathrm{UV} / \mathrm{H}_{2} \mathrm{O}_{2}+$ $\mathrm{GAC} F / \mathrm{A})$ 을 통해 처리됨을 확인할 수 있었다. 각 정수장의 공정별 제거율(前공정 대비)은 G정수장 Post Peroxone 45 100\%, GAC $14 \sim 58 \%$, I정수장 $\mathrm{UV} / \mathrm{H}_{2} \mathrm{O}_{2}$ 67 85\%, GAC F/A 20 50\%로 나타 났다.

$\mathrm{G}$ 정수장의 경우, 해당 시기에 Post Peroxone을 처음 운영함에
따라, $\mathrm{O}_{3}$ 및 $\mathrm{H}_{2} \mathrm{O}_{2}$ 주입률 결정 시행착오로 인해 Post Peroxone 을 통한 2-MIB 제거율에 편차가 있었다. 이후 $\mathrm{O}_{3}$ 주입률 0.9 $\mathrm{mg} / \mathrm{L}, \mathrm{H}_{2} \mathrm{O}_{2}$ 주입률 $0.36 \mathrm{mg} / \mathrm{L}$ 수준으로 운영함에 따라 전체 공정을 통하여 2-MIB를 86 100\% 제거할 수 있었다. I정수장 의 경우, 해당 시기의 $\mathrm{H}_{2} \mathrm{O}_{2}$ 주입률을 유사한 수준 $(5 \sim 7 \mathrm{mg} / \mathrm{L})$ 으로 운영하여 $\mathrm{UV} / \mathrm{H}_{2} \mathrm{O}_{2}$ 를 통한 2-MIB 제거율의 편차는 적었 다. 이를 통하여 $\mathrm{AOP}$ 운영 조건이 2-MIB 처리율에 큰 영향을 미침을 확인할 수 있었다.

각 정수장별 $\mathrm{GAC}$ 의 $\mathrm{BV}(\mathrm{Bed}$ Volume, $\mathrm{GAC}$ 단위 부피당 누적 통수량)는 $\mathrm{G}$ 정수장 37 천 256천 $\mathrm{m}^{3} / \mathrm{m}^{3}$ (평균 100 천 $\mathrm{m}^{3} / \mathrm{m}^{3}$ ), I정수장 35 천 54 천 $\mathrm{m}^{3} / \mathrm{m}^{3}$ (평균 44 천 $\mathrm{m}^{3} / \mathrm{m}^{3}$ ) 였으며, $\mathrm{GAC}$ 의 흡착성능에 영향을 미치는 요오드 흡착능은 $\mathrm{G}$ 정수장이 $177 \sim 1,022 \mathrm{mg} / \mathrm{g}$ (평균 $719 \mathrm{mg} / \mathrm{g}$ ), I정수장이 $808 \sim 821 \mathrm{mg} / \mathrm{g}$ (평 균 $815 \mathrm{mg} / \mathrm{g}$ )이었다. G정수장은 2009년 준공 후 $\mathrm{GAC}$ 를 지속 적으로 사용하며 순차적으로 교체 공사를 실시하였기 때문에, 2016년부터 GAC 공정을 운영한 I정수장에 비해 BV값이 크 고 요오드 흡착능이 낮으며 각 값의 편차가 큼을 확인할 수 있다. 그러나 $\mathrm{GAC}$ 에 의한 2-MIB 제거율은 G정수장이 I정수 장보다 더 높은 경향을 보이는데, 이는 $\mathrm{G}$ 정수장의 $\mathrm{GAC}$ 층고 가 높고 $(\mathrm{G}$ 정수장 $2.4 \mathrm{~m}$, I정수장 $1.7 \mathrm{~m})$ 선유속이 빠르기 $(\mathrm{G}$ 정 수장 $250 \mathrm{~m} /$ 일, I정수장 $180 \mathrm{~m} /$ 일) 때문인 것으로 사료된다. 

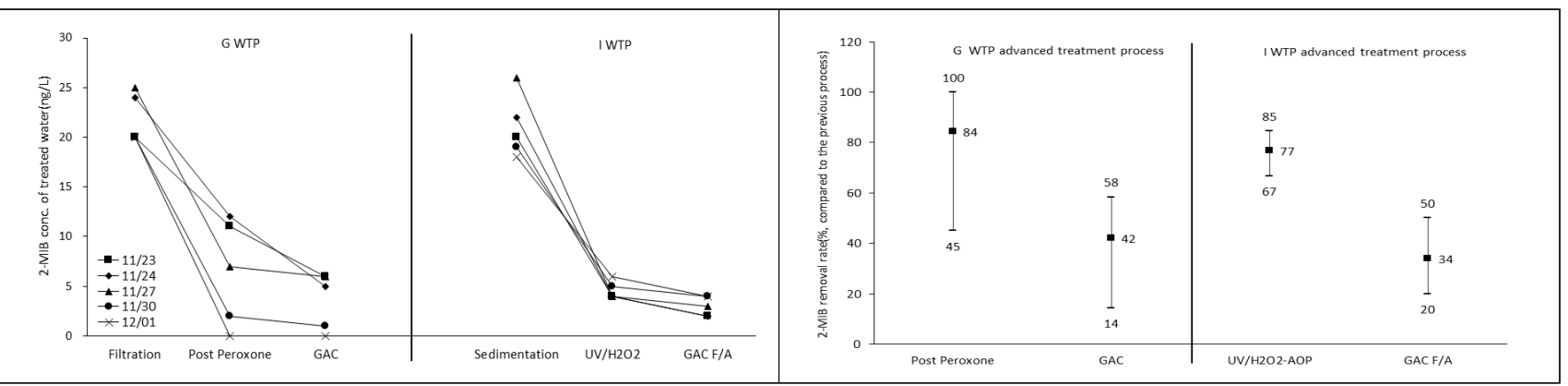

Fig. 7. Status of 2-MIB removal by each WTPs and processes.

또한, $\mathrm{F} / \mathrm{A}$ 의 경우 흡착과 탁질 제거를 함께 수행함에 따라 빈번한 역세척이 요구(역세척 주기 : G정수장 GAC 360 720 시간, I정수장 GAC F/A 72 96 시간)되므로, 미생물에 의한 생물학적 분해작용도 저하될 수 있을 것으로 예상된다. ${ }^{29)}$

$\mathrm{GAC}$ 의 장기간 운전 시 $\mathrm{GAC}$ 의 표면과 세공에 박테리아가 군집을 형성함으로써, $\mathrm{GAC}$ 의 흡착기작과 생물학적 분해 기 작이 동시에 유발되는 $\mathrm{BAC}$ (Biological activated carbon)가 되어 미량 유기물질에 대한 높은 제거능을 나타낼 수 있다. ${ }^{3031)}$ 석탄계 $\mathrm{BAC}$ 에 의한 2-MIB 처리 시, 수온 $5^{\circ} \mathrm{C}, 15^{\circ} \mathrm{C}, 25^{\circ} \mathrm{C}$ 에서 $\mathrm{EBCT}$ 를 20 분으로 운영할 경우 2-MIB 제거율이 각각 $71.7 \%$, $96 \%, 99 \%$ 로 나타난 연구 결과 ${ }^{32)}$ 가 있다. 이는 수온 저하 시 생물분해율의 저하가 나타나기 때문인 것으로 판단된다. 본 연구 진행 시기는 수온은 $69^{\circ} \mathrm{C}$ 인 동절기였음을 고려할 때,
고농도 2-MIB가 하절기에 발생하여 대응할 경우 GAC 공정에 의한 처리 효율은 더 높아질 수 있을 것으로 예상된다. 하절기 고수온시 GAC에 의한 2-MIB 처리 효율은 추후에 연구할 예 정이다.

\section{3. 각 정수장 $\mathrm{AOP}$ 별 운영 비용 분석}

2017년과 2018년 2-MIB 대응에 따른 각 정수장의 운영 조 건은 Table 3과 같다.

2017년과 2018년 2-MIB 대응에 따른 각 정수장의 운영비를 Fig. 8에 나타내었다.

$\mathrm{G}$ 정수장의 운영비는 $\mathrm{O}_{3}$ 발생기 운영을 위한 전력비, $\mathrm{O}_{3}$ 원 료인 $\mathrm{O}_{2}$ 구매비, Post Peroxone 반응을 위한 $\mathrm{H}_{2} \mathrm{O}_{2}$ 구매비 순으 로 나타났다. 특히 전력비와 $\mathrm{O}_{2}$ 구매비용은 $\mathrm{O}_{3}$ 발생농도에

Table 3. Operating conditions of each WTPs for 2-MIB treatment.

\begin{tabular}{ccc} 
& G WTP & I WTP \\
Water production (m ${ }^{3} /$ day $)$ & $192,033 \sim 238,890$ & $127,710 \sim 145,710$ \\
\hline $\mathrm{O}_{2}$ consumption $(\mathrm{kg} /$ day $)$ & $1,469 \sim 2,925$ & - \\
\hline $\mathrm{O}_{2}$ unit price $(\mathrm{KRW} / \mathrm{kg})$ & $138.6(2017 \mathrm{y}), 146.1(2018 \mathrm{y})$ & - \\
\hline $\mathrm{H}_{2} \mathrm{O}_{2}$ consumption $(\mathrm{kg} /$ day $)$ & $109 \sim 314$ & $1,535 \sim 4,823$ \\
\hline $\mathrm{H}_{2} \mathrm{O}_{2}$ unit price $(\mathrm{KRW} / \mathrm{kg})$ & $550(2017 \mathrm{y}), 660(2018 \mathrm{y})$ \\
\hline Electric power consumption $(\mathrm{kWh} /$ day) & $1974 \sim 5475$ & 4,968 \\
\hline Electric power unit price $(\mathrm{KRW} / \mathrm{kWh})$ & & 103.32 \\
\hline
\end{tabular}

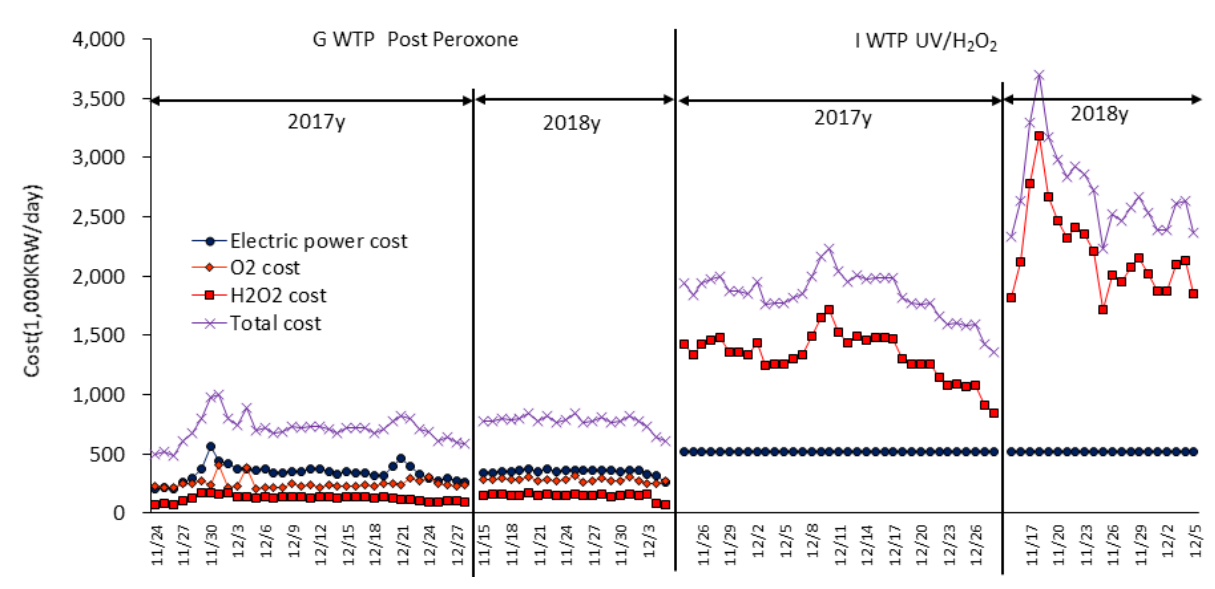

Fig. 8. Operating cost of each WTPs for 2-MIB treatment. 


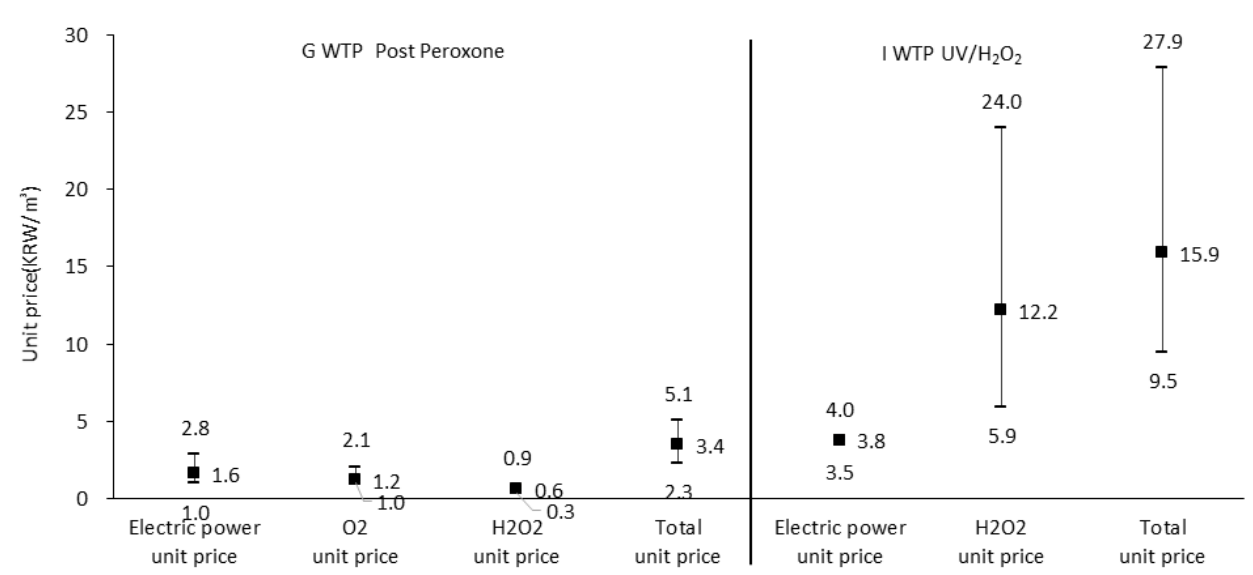

Fig. 9. AOP operating unit price of each WTPs.

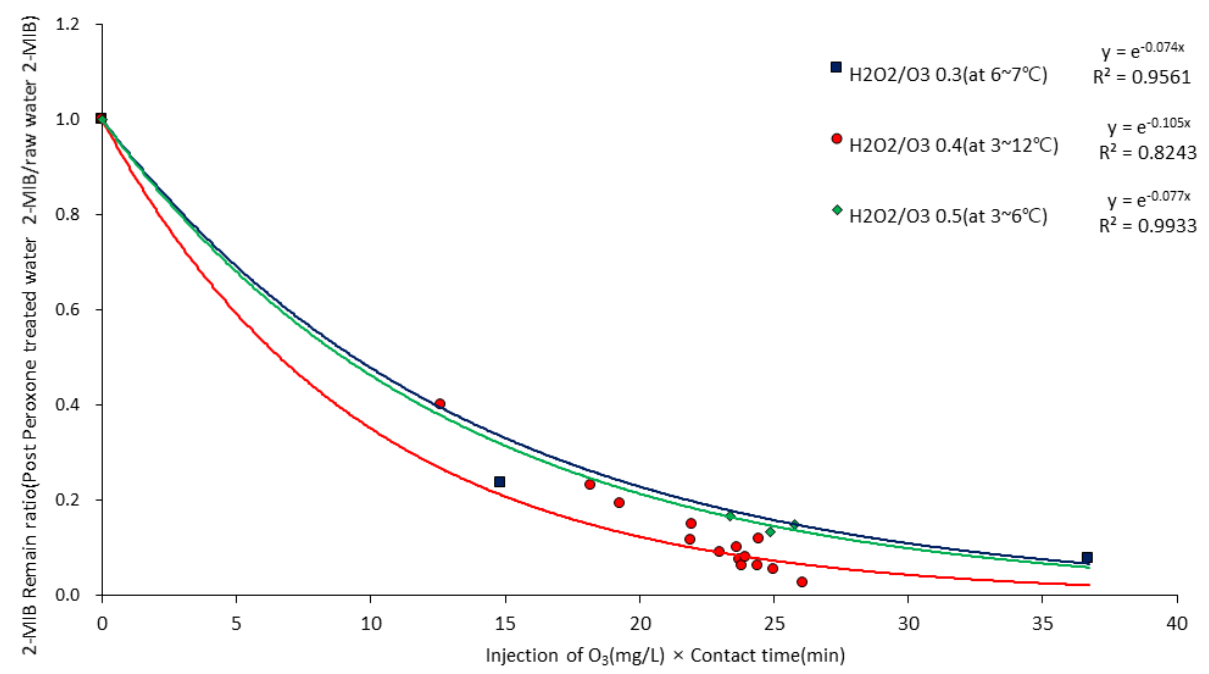

Fig. 10. 2-MIB remain ratio at different Peroxone operating condition in G WTP.

따라 서로 연계하여 변화하기 때문에, 경제성을 고려하여 최 적 $\mathrm{O}_{3}$ 발생농도를 결정하여야 한다.

I정수장은 $\mathrm{AOP}$ 반응을 위한 $\mathrm{H}_{2} \mathrm{O}_{2}$ 구매비용이 가장 큰 비중 을 차지하였다. UV 설비의 경우 설정 출력에 따라 전력 사용 량은 일정한 특징을 갖는다. I정수장에서는 2-MIB 대응 시 $\mathrm{UV}$ 설비를 $100 \%$ 출력으로 운영하여 전력 사용량은 변동이 없었다.

일일 총운영비는 $\mathrm{G}$ 정수장 486,330 1,003,082원, I정수장 $1,357,577 \sim 3,696,308$ 원으로 나타났다.

$\mathrm{G}$ 정수장이 I정수장보다 정수생산량이 40 80\% 더 많음을 고려 하여 두 공정의 운영비를 비교하기 위한 원단위 분석 결과를 Fig.9에 나타내었다. 총 원단위는 $\mathrm{UV} / \mathrm{H}_{2} \mathrm{O}_{2}$ 가 Post Peroxone 보다 $1 \mathrm{~m}^{3}$ 당 6.6 24.3원 더 높았다. 전력 원단위는 $\mathrm{UV} / \mathrm{H}_{2} \mathrm{O}_{2}$ 가 Post Peroxone보다 다소 높은 수준 $\left(0.8 \sim 2.8\right.$ 원 $\left./ \mathrm{m}^{3}\right)$ 이었으나, AOP 반응을 위한 $\mathrm{H}_{2} \mathrm{O}_{2}$ 의 주입률이 11 43배로 높았음을 고려할 때, 높은 $\mathrm{UV} / \mathrm{H}_{2} \mathrm{O}_{2}$ 원단위의 주요한 원인은 $\mathrm{H}_{2} \mathrm{O}_{2}$ 구매비로 확인되 었다. 해당 기간의 2-MIB 제거율이 UV/ $\mathrm{H}_{2} \mathrm{O}_{2}$ 보다 Post Peroxone 이 다소 높았음을 고려할 때, 동일한 수준의 2-MIB 제거율을
목표로 운영할 경우 두 공정의 원단위 차이는 더욱 커질 것으로 예상된다. $\mathrm{UV} / \mathrm{H}_{2} \mathrm{O}_{2}$ 의 2-MIB 제거 특성을 고려할 때, $\mathrm{UV}$ 조사량 을 높이면 전력비는 상승할 수 있으나 $\mathrm{H}_{2} \mathrm{O}_{2}$ 주입률은 저감시킬 수 있다. 전력 원단위가 $\mathrm{H}_{2} \mathrm{O}_{2}$ 원단위보다 저렴함을 고려할 때, $\mathrm{UV} / \mathrm{H}_{2} \mathrm{O}_{2}$ 의 경제성을 제고하기 위해서는 UV 조사량을 증가시켜 운영할 필요가 있다.

기존의 표준처리 정수장에 Post $\mathrm{O}_{3}$ 과 $\mathrm{GAC}$ 를 증설하는 경 우, $\mathrm{GAC}$ 처리수를 정수지로 송수하기 위한 중간가압장이 필요할 수 있다. 이 경우 중간가압장 운영을 위한 전력 원단 위는 시설 특성(수리단면, 수두차, 용량 등)에 따라 다르지만 약 3 4원 $/ \mathrm{m}^{3}$ 수준이다. $\mathrm{G}$ 정수장은 설계단계부터 고도처리 공정 도입을 고려하였기 때문에 중간가압장이 불필요하나, 중간가압장 운영이 필요하여 전력 원단위가 최대 4 원 $/ \mathrm{m}^{3}$ 상 승하였다고 가정해도 I정수장보다 총원단위는 저렴하게 산 정된다.

\section{4. 각 정수장 AOP별 2-MIB 처리 특성 분석 결과}

Fig. 10은 $\mathrm{G}$ 정수장의 $\mathrm{O}_{3}$ 주입률과 접촉시간, $\mathrm{H}_{2} \mathrm{O}_{2}$ 와 $\mathrm{O}_{3}$ 의 
비율 $\left(\mathrm{H}_{2} \mathrm{O}_{2} / \mathrm{O}_{3}\right)$ 에 따른 2-MIB 제거효율 분석 결과이다. 정수 2-MIB 농도가 불검출인 경우의 운영 조건은 약품 $\left(\mathrm{O}_{3}, \mathrm{H}_{2} \mathrm{O}_{2}\right)$ 이 과량 주입된 것으로 판단하여 해당 데이터를 배제하고 상관관 계를 도출하였다. 2-MIB의 잔류율은 1 차 반응에 따라 $\left[\mathrm{O}_{3}\right.$ 주 입률×접촉시간]의 값이 클수록 감소하는 경향을 나타내었다. $\mathrm{H}_{2} \mathrm{O}_{2} / \mathrm{O}_{3}$ 역시 Post Peroxone 최적 운영을 위한 중요한 요소로 작용한다. 여러 연구 결과에서 $\mathrm{H}_{2} \mathrm{O}_{2} / \mathrm{O}_{3}$ 는 $0.2 \sim 1.4$ 로 다양하게 제시됨 ${ }^{33}$ 에 따라, 각 정수장에서는 실공정에서의 처리 효율을 고려하여 결정하여야 한다. 2017년과 2018년의 2-MIB 대응 시 다양한 $\mathrm{O}_{3}$ 주입률과 $\mathrm{H}_{2} \mathrm{O}_{2} / \mathrm{O}_{3}$ 를 적용한 결과, 2-MIB 잔류율 은 $\left[\mathrm{O}_{3}\right.$ 주입률×접촉시간 $]$ 값이 클수록 감소하는 경향을 나타내 었다. 또한, $\left[\mathrm{O}_{3}\right.$ 주입률×접촉시간]과 2-MIB 잔류율 상관관계 식의 $\mathrm{H}_{2} \mathrm{O}_{2} / \mathrm{O}_{3}$ 별 감소계수는 $0.074 \sim 0.105\left(\mathrm{R}^{2}=0.8243 \sim 0.9933\right)$ 로, $\mathrm{H}_{2} \mathrm{O}_{2} / \mathrm{O}_{3}$ 0.4일 때의 효율이 가장 높음을 확인할 수 있었다.

$\mathrm{G}$ 정수장의 $\left[\mathrm{O}_{3}\right.$ 주입률×접촉시간]과 2-MIB 잔류율 분석을 통하여 다음과 같은 Post Peroxone 약품 $\left(\mathrm{O}_{3}, \mathrm{H}_{2} \mathrm{O}_{2}\right)$ 주입률 산 정식(1)을 도출할 수 있었다.

$$
\begin{array}{ll}
\mathrm{PO}_{3}=\frac{\ln \left(M_{P} / M_{I}\right)}{-0.105 \times T} & \left(\text { at } 3 \sim 12^{\circ} \mathrm{C}\right) \\
\mathrm{PH}_{2} \mathrm{O}_{2}=0.4 \times \mathrm{PO}_{3} & \left(\text { at } 3 \sim 12^{\circ} \mathrm{C}\right)
\end{array}
$$

where, $\mathrm{PO}_{3}: \mathrm{O}_{3}$ injection for Post Peroxone $(\mathrm{mg} / \mathrm{L})$

$\mathrm{M}_{\mathrm{P}}$ : target concentration of 2-MIB by Post Peroxone (ng/L)

$\mathrm{M}_{\mathrm{I}}$ : influent concentration of 2-MIB (ng/L)

$\mathrm{T}$ : contact time of $\mathrm{O}_{3}(\mathrm{~min})$

$\mathrm{PH}_{2} \mathrm{O}_{2}: \mathrm{H}_{2} \mathrm{O}_{2}$ injection for Post Peroxone (mg/L)

Fig. 11은 I정수장의 UV 조사량과 $\mathrm{H}_{2} \mathrm{O}_{2}$ 주입률에 따른 2-MIB 제거효율 분석 결과이다. $\mathrm{UV}$ 조사량 $\left(\mathrm{mJ} / \mathrm{cm}^{2}\right)$ 은 $\mathrm{UV}$ 조사 강도계의 측정값 $\left(\mathrm{mW} / \mathrm{cm}^{2}\right) \times \mathrm{UV}$ 접촉시간 $(\mathrm{sec})$ 으로 계 산하였다.

2-MIB의 잔류율은 1차 반응에 따라 UV 조사량 $\times \mathrm{H}_{2} \mathrm{O}_{2}$ 주입 률의 값이 클수록 감소하는 경향을 나타내었다.

I정수장의 UV 조사량 $\times \mathrm{H}_{2} \mathrm{O}_{2}$ 주입률과 2-MIB 잔류율 분석 을 통하여 다음과 같은 $\mathrm{H}_{2} \mathrm{O}_{2}$ 주입률 산정식(2)를 도출할 수 있었다.

$$
U H_{2} O_{2}=\frac{\ln \left(M_{U} / M_{I}\right)}{-3.668 \times 10^{-4} \times U_{D}} \quad\left(a t 3 \sim 12^{\circ} \mathrm{C}\right)
$$

where, $\mathrm{UH}_{2} \mathrm{O}_{2}: \mathrm{H}_{2} \mathrm{O}_{2}$ injection for $\mathrm{UV} / \mathrm{H}_{2} \mathrm{O}_{2}(\mathrm{mg} / \mathrm{L})$

$\mathrm{M}_{\mathrm{U}}$ : target concentration of 2-MIB by $\mathrm{UV} / \mathrm{H}_{2} \mathrm{O}_{2}$ (ng/L)

$\mathrm{M}_{\mathrm{I}}$ : influent concentration of 2-MIB (ng/L)

$\mathrm{U}_{\mathrm{D}}: \mathrm{UV}$ dose $\left(\mathrm{mJ} / \mathrm{cm}^{2}\right)$

UV dose $\left(\mathrm{mJ} / \mathrm{cm}^{2}\right)=\mathrm{UV}$ intensity $\left(\mathrm{mW} / \mathrm{cm}^{2}\right)$ $\times$ contact time $(\mathrm{sec})$

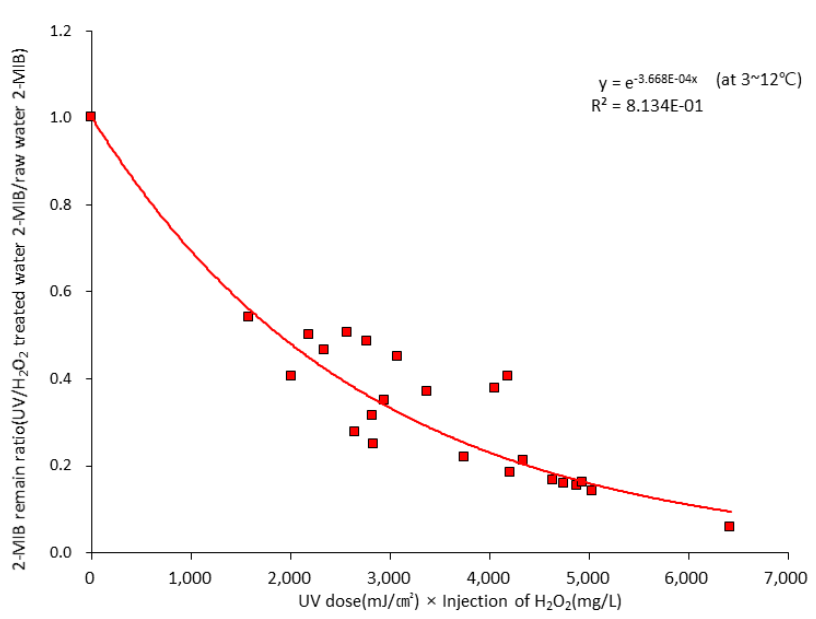

Fig. 11. 2-MIB remain ratio at different $\mathrm{UV} / \mathrm{H}_{2} \mathrm{O}_{2}$ operating condition in I WTP.

Peroxone을 통한 2-MIB 처리 시 수온 $5^{\circ} \mathrm{C}, 25^{\circ} \mathrm{C}$ 에서 $\mathrm{O}_{3}$ 주입률 제거율 $1.5 \mathrm{mg} / \mathrm{L}$ 로 운영할 경우, 고수온 대비 저수온 시의 2-MIB 제거율이 $18 \sim 28 \%$ p 더 낮게 나타났으며 적정 $\mathrm{H}_{2} \mathrm{O}_{2} / \mathrm{O}_{3}$ 도 달라질 수 있다는 연구 결과가 있다. ${ }^{27)}$ 이는 수온 저하 시 화학반응 속도의 저하가 나타나기 때문인 것으로 판 단되며, $\mathrm{UV} / \mathrm{H}_{2} \mathrm{O}_{2}$ 역시 수온의 영향을 받을 수 있을 것으로 예상된다. 본 연구가 이루어진 2017년과 2018년에는 고농도 의 2-MIB가 동절기인 11 12월에 주로 발생하였으며 해당 시 기의 수온은 $3 \sim 12^{\circ} \mathrm{C}$ 였다. $\mathrm{AOP}$ 에 의한 2-MIB 처리율이 저수 온 시에 감소함을 고려한다면, 본 연구 결과는 worst case로서 $3 \sim 12^{\circ} \mathrm{C}$ 수온 조건에 적용할 수 있으며 고농도 2-MIB가 하절 기에 발생하여 대응할 경우 $\mathrm{AOP}$ 공정에 의한 처리 효율은 더 높아질 수 있을 것으로 예상된다. 하절기 고수온시 $\mathrm{AOP}$ 에 의한 2-MIB 처리 효율 및 최적 $\mathrm{H}_{2} \mathrm{O}_{2} / \mathrm{O}_{3}$ 등은 추후에 연구할 예정이다.

$\mathrm{UV}$ 에 의해 1 몰의 $\mathrm{H}_{2} \mathrm{O}_{2}$ 가 2 몰의 $\mathrm{OH} \cdot$ 로 분해되나, 실공정에 서 $\mathrm{H}_{2} \mathrm{O}_{2}$ 의 분해율은 $5 \%$ 이하 수준이다. 이에 따라 2-MIB 제거를 위해서는 고농도의 $\mathrm{H}_{2} \mathrm{O}_{2}$ 주입이 필요하며, 주입된 $\mathrm{H}_{2} \mathrm{O}_{2}$ 의 $95 \%$ 이상은 이후 공정으로 유출된다. 정수장 운영 시 잔류 $\mathrm{H}_{2} \mathrm{O}_{2}$ 가 후속 공정에서 제거되지 않을 경우, 후염소와 반응하여 소독 및 관망 잔류염소 농도 확보에 영향을 미칠 수 있다.

I정수장의 공정별 $\mathrm{H}_{2} \mathrm{O}_{2}$ 농도를 Fig. 12에 나타내었다. $\mathrm{UV} / \mathrm{H}_{2} \mathrm{O}_{2}$ 후속 공정으로 $\mathrm{GAC} \mathrm{F} / \mathrm{A}$ 를 운영할 경우 잔류 $\mathrm{H}_{2} \mathrm{O}_{2}$ 는 대부분 $\mathrm{GAC} \mathrm{F} / \mathrm{A}$ 에서 제거됨을 확인할 수 있었다.

\section{5. 각 정수장 $\mathrm{AOP}$ 별 최적 운영방안 도출}

\subsubsection{G정수장 Post Peroxone}

2-MIB 처리를 위한 Post Peroxone 운영 최적화를 위해서는 $\mathrm{O}_{3}$ 발생기의 경제적인 운영과 적정 $\mathrm{O}_{3}$ 및 $\mathrm{H}_{2} \mathrm{O}_{2}$ 주입이 필요하 다. 2019년 $\mathrm{G}$ 정수장 기술진단 시 $\mathrm{O}_{3}$ 발생기의 성능평가를 실시하여 경제적인 운영 기준을 결정하였으며, 약품 주입률 


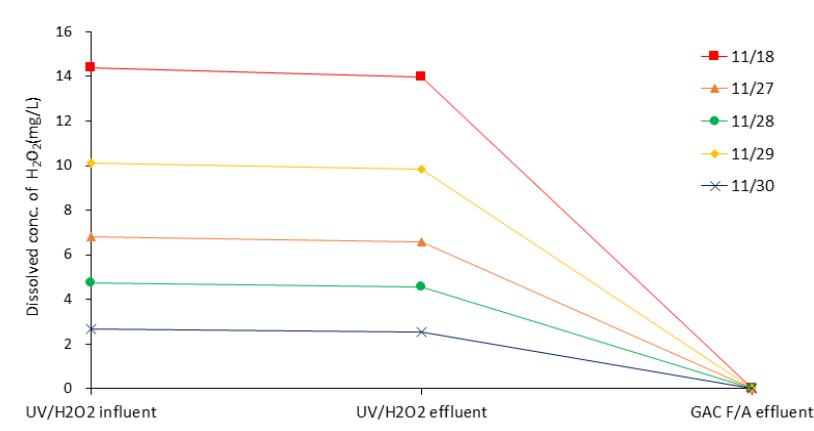

Fig. 12. Status of $\mathrm{H}_{2} \mathrm{O}_{2}$ concentration of treated water in I WTP.

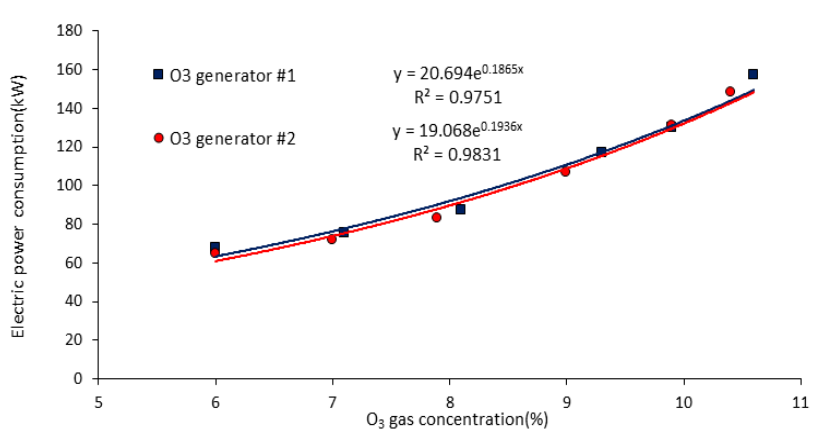

Fig. 13. Correlation between $\mathrm{O}_{3}$ gas concentration and electric power.

Table 4. $\mathrm{O}_{3}$ generators operating conditions and results for performance test.

\begin{tabular}{|c|c|c|c|c|c|c|c|c|c|c|c|c|}
\hline \multirow[b]{2}{*}{$\mathrm{O}_{3}$ concentration (\%) } & \multicolumn{6}{|c|}{$\mathrm{O}_{3}$ generator 1} & \multicolumn{6}{|c|}{$\mathrm{O}_{3}$ generator 2} \\
\hline & 6.0 & 7.1 & 8.1 & 9.3 & 9.9 & 10.6 & 6.0 & 7.0 & 7.9 & 9.0 & 9.9 & 10.4 \\
\hline $\mathrm{O}_{3}$ production $(\mathrm{kg} / \mathrm{hr})$ & 10.3 & 10.6 & 10.6 & 12.2 & 11.7 & 11.0 & 10.3 & 10.3 & 10.4 & 11.4 & 11.4 & 10.9 \\
\hline Electric power consumption (kWh) & 68 & 75 & 87 & 117 & 130 & 157 & 65 & 72 & 83 & 107 & 131 & 148 \\
\hline Electric power unit cost (KRW/kWh) & \multicolumn{12}{|c|}{103.32} \\
\hline $\mathrm{O}_{2}$ consumption $(\mathrm{kg} / \mathrm{hr})$ & 172 & 149 & 131 & 131 & 118 & 104 & 172 & 148 & 132 & 127 & 115 & 105 \\
\hline $\mathrm{O}_{2}$ unit cost $(\mathrm{KRW} / \mathrm{kg})$ & \multicolumn{12}{|c|}{173.91} \\
\hline
\end{tabular}

산정식(1)을 통하여 원수 2-MIB 농도에 따른 적정 $\mathrm{O}_{3}$ 및 $\mathrm{H}_{2} \mathrm{O}_{2}$ 주입률을 도출하였다.

$\mathrm{O}_{3}$ 발생기의 성능평가 시 운영 조건 및 결과는 Table4와 같다.

$\mathrm{G}$ 정수장 $\mathrm{O}_{3}$ 발생기의 $\mathrm{O}_{3}$ 발생농도별 소비전력량 분석 결과 를 Fig. 13에 나타내었다. 오존 발생량은 최대 생산용량인 10.5 $\mathrm{kg} / \mathrm{hr}$ 로 설정하였으며, $\mathrm{O}_{3}$ 발생농도가 증가함에 따라 소비전 력량은 지수적으로 증가함을 확인할 수 있었다. $\mathrm{O}_{3}$ 발생기의 최대 $\mathrm{O}_{3}$ 발생농도는 $10.5 \%$ 수준이었다.

$\mathrm{O}_{3}$ 발생기의 최적 운영 조건은 $\mathrm{O}_{3}$ 발생기의 운영 조건별 전력 소비량, 전력비, $\mathrm{O}_{2}$ 사용량, $\mathrm{O}_{2}$ 구매비를 종합하여 결정 할 수 있다. $\mathrm{O}_{3}$ 발생농도가 높으면 전력 소비량이 증가하지만 $\mathrm{O}_{2}$ 사용량은 감소한다. $\mathrm{G}$ 정수장 $\mathrm{O}_{3}$ 발생기의 $\mathrm{O}_{3}$ 발생농도별 전력 및 $\mathrm{O}_{2}$ 원단위 비교 분석 결과, $9 \%$ 의 $\mathrm{O}_{3}$ 발생농도가 최적 운영 조건임을 확인할 수 있었다(Fig. 14).

Post Peroxone 약품 $\left(\mathrm{O}_{3}, \mathrm{H}_{2} \mathrm{O}_{2}\right)$ 주입률 산정식(1)을 활용하여, 원수 2-MIB 농도와 시설 이용률별 최적 약품 주입률을 도출하 였다(Fig.15). 정수의 목표 2-MIB 농도는 K-water 자체 기준 인 $10 \mathrm{ng} / \mathrm{L}$ 의 $80 \%$ 수준인 $8 \mathrm{ng} / \mathrm{L}$ 로 설정하였으며, $\mathrm{GAC}$ 를 통한 2-MIB 제거율은 前공정의 42\%(2017년 평균 제거율 적 용)를 적용하였다. 시설 이용률은 현재 시설용량 $\left(210,000 \mathrm{~m}^{3} /\right.$ 일)과 장래분 증설 완료 시의 시설용량 $\left(350,000 \mathrm{~m}^{3} /\right.$ 일) 각각의 $80,100,120 \%$ 로 설정하였다.

원수 2-MIB $300 \mathrm{ng} / \mathrm{L}$ 유입 시 $\mathrm{O}_{3}$ 주입률은 용수생산량에 따라 $0.87 \sim 2.18 \mathrm{mg} / \mathrm{L}, \mathrm{H}_{2} \mathrm{O}_{2}$ 주입률은 $0.35 \sim 0.87 \mathrm{mg} / \mathrm{L}$ 로 산정 되었다. 원수의 2-MIB 농도가 동일한 조건에서 시설 이용률이
증가할수록 $\mathrm{O}_{3}$ 접촉시간이 짧아져, $\mathrm{O}_{3}$ 의 주입률은 높아진다. 장래분 도입 시 $\mathrm{O}_{3}$ 발생기는 1 대가 증설될 예정이나, $\mathrm{O}_{3}$ 접촉 조는 장래분을 포함하여 건설이 완료된 시설물로 증설은 실시 하지 않을 예정이다. 이에 따라, 장래분 도입으로 용수생산량 이 증가할 경우, $\mathrm{O}_{3}$ 접촉시간이 더욱 단축됨에 따라 $\mathrm{O}_{3}$ 주입률 은 더 높아질 것으로 예상된다. 따라서 $\mathrm{O}_{3}$ 발생기 신규 도입 시, 고농도 2-MIB 발생시에도 정수 목표 2-MIB 농도를 충족 할 수 있도록 용수생산량은 물론 $\mathrm{O}_{3}$ 주입률을 고려하여 $\mathrm{O}_{3}$ 발생기의 용량을 결정하여야 한다.

용수생산량 및 원수 2-MIB 농도별 Post Peroxone 운영 원단 위를 Fig.16에 나타내었다. 전력 및 약품 단가는 2020년 단가 를 적용하였다(전력 103.32원 $/ \mathrm{kW}, \mathrm{O}_{2}$ 192.2원 $/ \mathrm{kg}, \mathrm{H}_{2} \mathrm{O}_{2} 594$ 원 $/ \mathrm{kg}$ ). 원수 2-MIB $300 \mathrm{ng} / \mathrm{L}$ 유입 시 운영비 원단위(전력비 $+\mathrm{O}_{2}$ 구매비 $+\mathrm{H}_{2} \mathrm{O}_{2}$ 구매비)는 용수생산량에 따라 3.4 8.4원 $/ \mathrm{m}^{3}$ 으로 산정되었다. 용수생산량 증가 시 $\mathrm{O}_{3}$ 접촉시간이 감소 함에 따라 $\mathrm{O}_{3}$ 및 $\mathrm{H}_{2} \mathrm{O}_{2}$ 의 주입률이 상승하여 운영 원단위가 증가함을 확인할 수 있었다.

\subsubsection{I정수장 UV/ $\mathrm{H}_{2} \mathrm{O}_{2}$}

2-MIB 처리를 위한 $\mathrm{UV} / \mathrm{H}_{2} \mathrm{O}_{2}$ 운영 최적화를 위해서는 $\mathrm{UV} / \mathrm{H}_{2} \mathrm{O}_{2}$ 설비의 경제적인 운영과 적정 $\mathrm{H}_{2} \mathrm{O}_{2}$ 주입이 필요하 다. $\mathrm{UV} / \mathrm{H}_{2} \mathrm{O}_{2}$ 성능을 분석하여 경제적인 운영 기준을 결정하 였으며, $\mathrm{H}_{2} \mathrm{O}_{2}$ 주입률 산정식(2)를 통하여 원수 2-MIB 농도에 따른 적정 $\mathrm{H}_{2} \mathrm{O}_{2}$ 주입률을 도출하였다.

$\mathrm{UV} / \mathrm{H}_{2} \mathrm{O}_{2}$ 설비의 성능 분석을 위한 운영 조건 및 결과는 Table 5와 같다. 용수생산량은 현재 시설용량인 $150,000 \mathrm{~m}^{3} /$ 


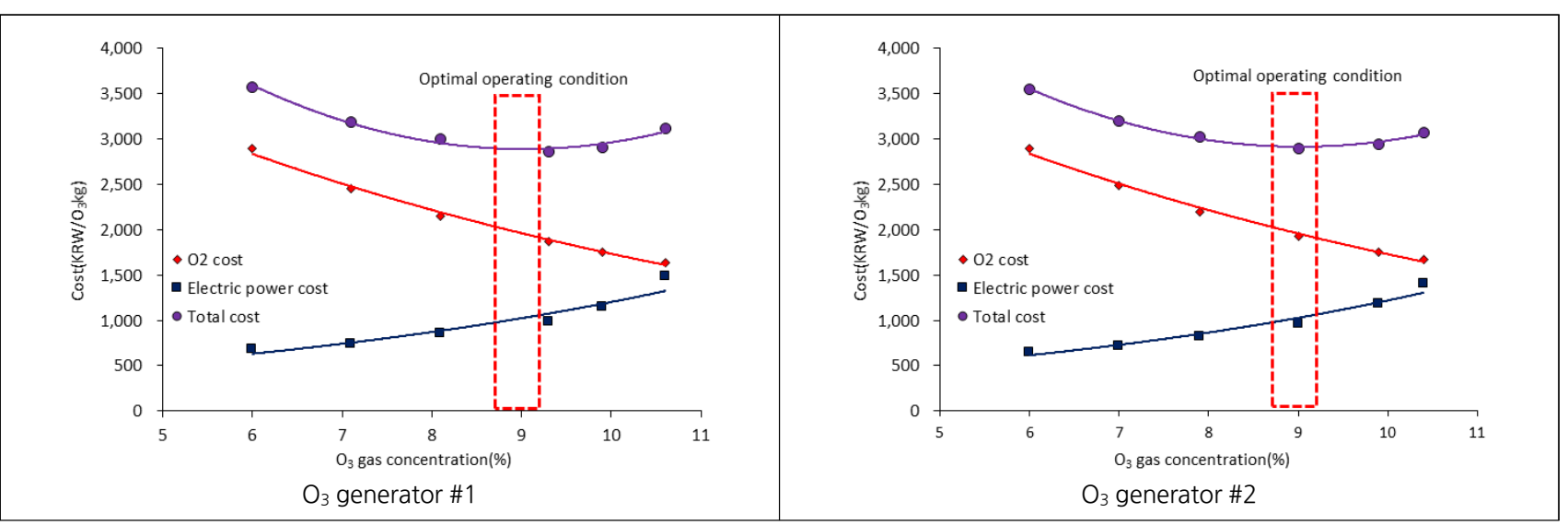

Fig. 14. Operating cost of each $\mathrm{O}_{3}$ generators.

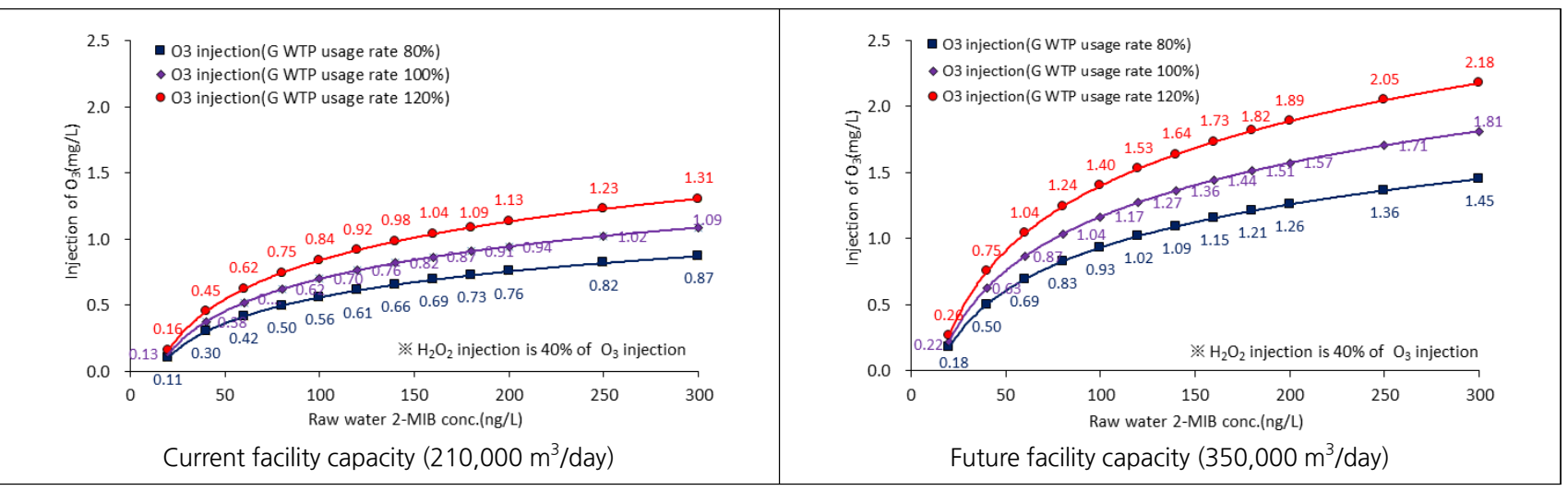

Fig. 15. $\mathrm{O}_{3} \& \mathrm{H}_{2} \mathrm{O}_{2}$ injection by raw water 2-MIB concentration and water product of G WTP.
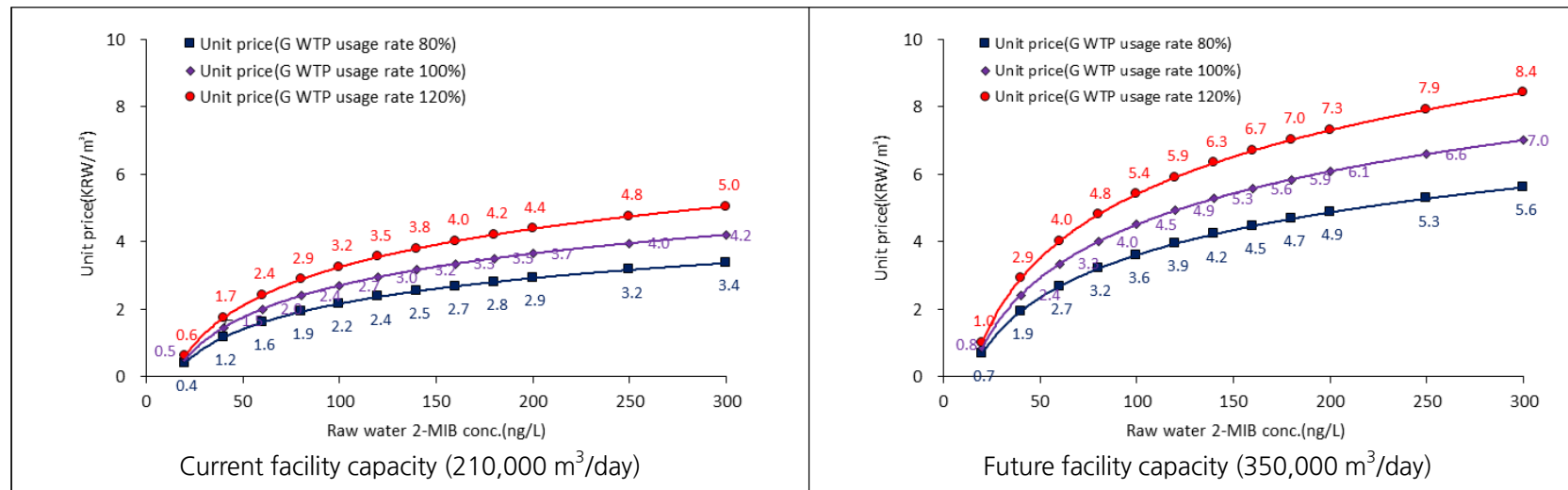

Fig. 16. Unit price by raw water 2-MIB concentration and water product of G WTP.

일, 원수 2-MIB 농도는 $50 \mathrm{ng} / \mathrm{L}, \mathrm{UV} / \mathrm{H}_{2} \mathrm{O}_{2}$ 처리를 통한 목표 2-MIB 농도는 $15 \mathrm{ng} / \mathrm{L}$ 를 적용하였다.

$\mathrm{UV} / \mathrm{H}_{2} \mathrm{O}_{2}$ 설비의 최적 운영 조건은 설비 출력별 전력 소비 량, 전력비, $\mathrm{H}_{2} \mathrm{O}_{2}$ 사용량, $\mathrm{H}_{2} \mathrm{O}_{2}$ 구매비를 종합하여 결정할 수 있다. 설비 출력이 높으면 전력 소비량이 증가하지만 $\mathrm{H}_{2} \mathrm{O}_{2}$ 사용량은 감소한다. $\mathrm{I}$ 정수장 $\mathrm{UV} / \mathrm{H}_{2} \mathrm{O}_{2}$ 설비의 출력별 전력 및 $\mathrm{H}_{2} \mathrm{O}_{2}$ 원단위 비교 분석 결과, $100 \%$ 의 출력이 최적 운영 조건 임을 확인할 수 있었다(Fig. 17).

$\mathrm{H}_{2} \mathrm{O}_{2}$ 주입률 산정식(2)를 활용하여, 원수 2-MIB 농도와 시
설 이용률별 최적 $\mathrm{H}_{2} \mathrm{O}_{2}$ 주입률을 도출하였다(Fig. 18). 정수의 목표 2-MIB 농도는 K-water 자체 기준인 $10 \mathrm{ng} / \mathrm{L}$ 의 $80 \%$ 수준 인 $8 \mathrm{ng} / \mathrm{L}$ 로 설정하였으며, $\mathrm{UV}$ 강도는 $100 \%$ 출력시의 평균인 $25 \mathrm{~mW} / \mathrm{cm}^{2}, \mathrm{GAC} \mathrm{F} / \mathrm{A}$ 를 통한 2-MIB 제거율은 前공정의 $34 \%$ (2017년 평균 제거율 적용)를 적용하였다. 시설 이용률은 현재 시설용량 $\left(150,000 \mathrm{~m}^{3} /\right.$ 일)과 2단계 도입 완료시의 시설용 량 $\left(250,000 \mathrm{~m}^{3} /\right.$ 일 $)$ 각각의 $80,100,120 \%$ 로 설정하였다. 2 단계 도입설비의 대상 유량은 $100,000 \mathrm{~m}^{3} /$ 일로 1 단계의 $80 \%$ 이나, $\mathrm{UV} / \mathrm{H}_{2} \mathrm{O}_{2}$ 설비의 2-MIB 제거율 기준이 $85 \%$ 로 상향(기존 
Table 5. UV/ $\mathrm{H}_{2} \mathrm{O}_{2}$ facility operating conditions and results for performance test.

\begin{tabular}{|c|c|c|c|c|}
\hline UV facility output (\%) & 30 & 50 & 70 & 100 \\
\hline UV intensity $\left(\mathrm{mW} / \mathrm{cm}^{2}\right)$ & 7.5 & 12.5 & 17.5 & 25.0 \\
\hline UV dose $\left(\mathrm{mJ} / \mathrm{cm}^{2}\right)$ & 122 & 203 & 284 & 406 \\
\hline Electric power consumption (kWh) & 73 & 111 & 149 & 207 \\
\hline Electric power unit cost (KRW/kWh) & \multicolumn{4}{|c|}{103.32} \\
\hline $\mathrm{H}_{2} \mathrm{O}_{2}$ consumption (kg/day) & 11,887 & 7,132 & 5,094 & 3,566 \\
\hline $\mathrm{H}_{2} \mathrm{O}_{2}$ unit cost $(\mathrm{KRW} / \mathrm{kg})$ & & & & \\
\hline
\end{tabular}

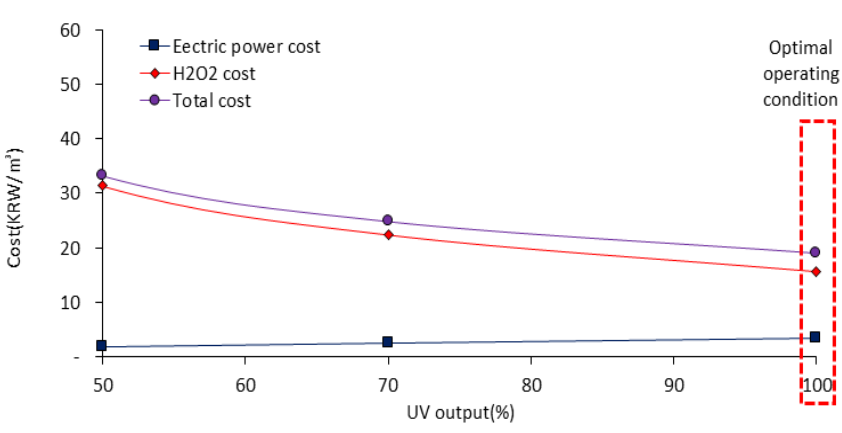

Fig. 17. Operating cost of $\mathrm{UV} / \mathrm{H}_{2} \mathrm{O}_{2}$ facility.
$70 \%$ )됨에 따라 2단계 도입 설비의 UV 출력은 1단계와 유사할 것으로 예상된다. 따라서 $\mathrm{H}_{2} \mathrm{O}_{2}$ 주입률 도출 시 현재 시설용량 조건에서는 UV 반응조 2개(UV lamp 총출력 $192 \mathrm{~kW}$, 접촉용 량 $\left.28.2 \mathrm{~m}^{3}\right), 2$ 단계 도입 완료 시 시설용량 조건에서는 $\mathrm{UV}$ 반응조 4개(UV lamp 총출력 $384 \mathrm{~kW}$, 접촉용량 $\left.56.4 \mathrm{~m}^{3}\right)$ 를 적용하였다.

원수 2-MIB $300 \mathrm{ng} / \mathrm{L}$ 유입 시 $\mathrm{H}_{2} \mathrm{O}_{2}$ 주입률은 $14 \sim 26 \mathrm{mg} / \mathrm{L}$ 로 산정되었다. 원수의 2-MIB 농도가 동일한 조건에서 시설 이용 률이 증가할수록 UV 접촉시간이 짧아져, $\mathrm{UV}$ 조사량이 감소 함에 따라 $\mathrm{H}_{2} \mathrm{O}_{2}$ 의 주입률은 높아진다. 장래분 도입 시 용수생

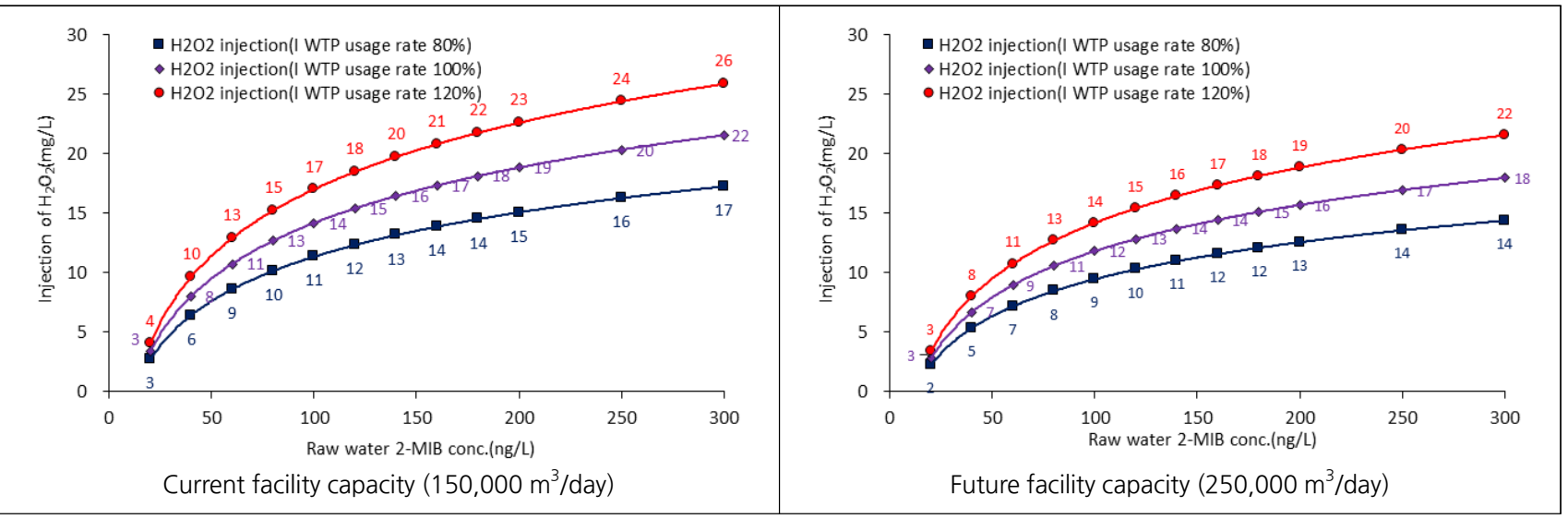

Fig. 18. $\mathrm{H}_{2} \mathrm{O}_{2}$ injection by raw water 2-MIB concentration and water product of I WTP.

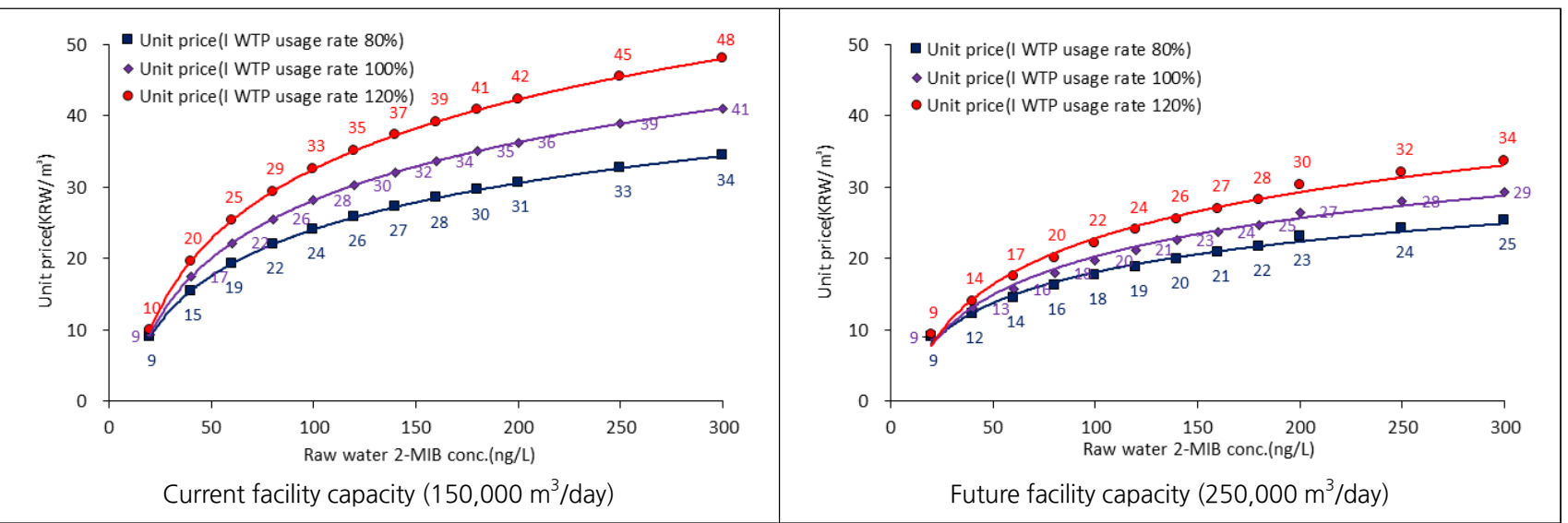

Fig. 19. Unit price by raw water 2-MIB concentration and water product of I WTP. 


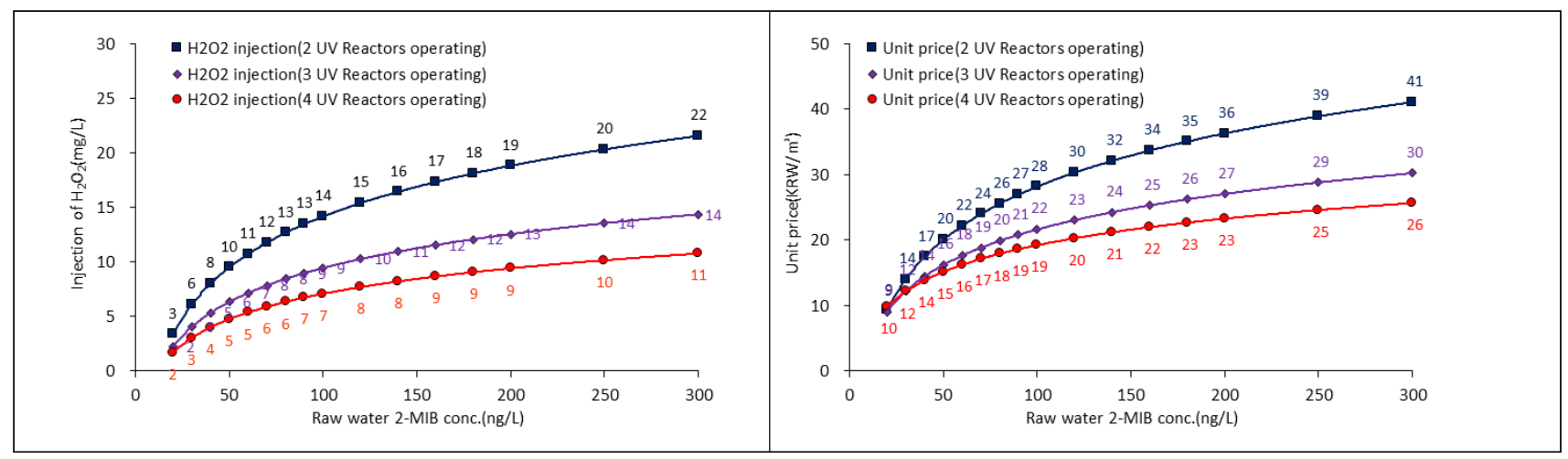

Fig. 20. $\mathrm{H}_{2} \mathrm{O}_{2}$ injection and Unit price by number of UV reactors operating.

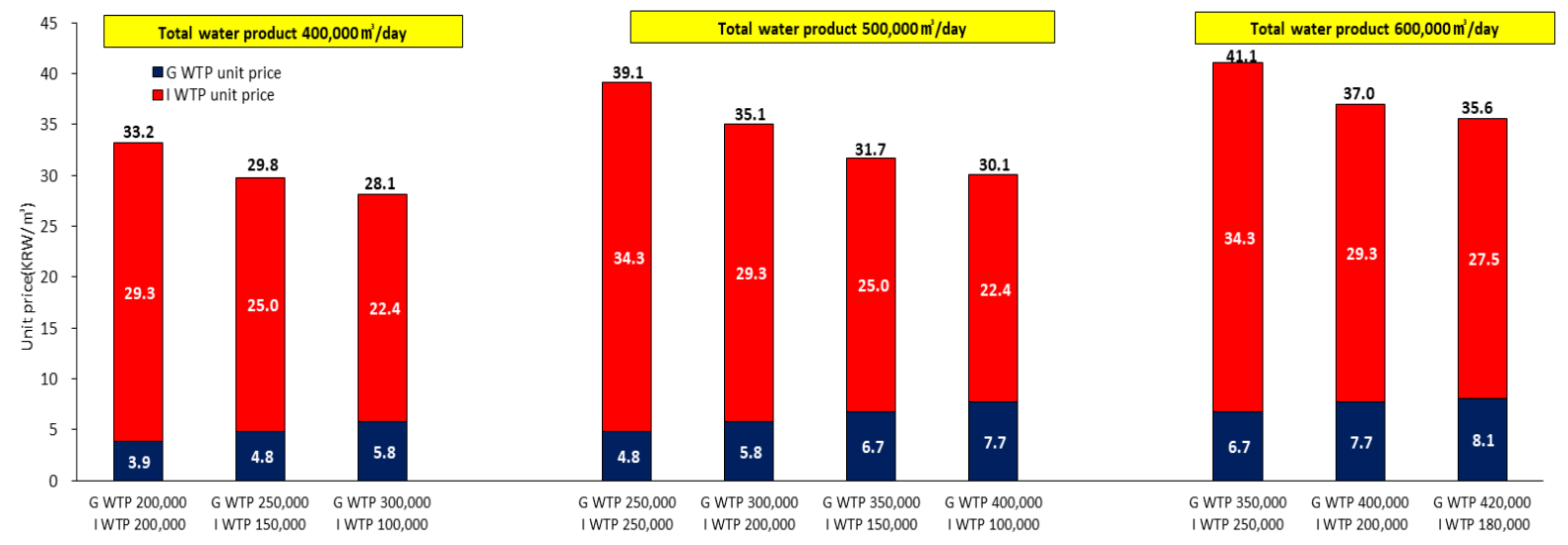

Fig. 21. Unit price by water distribution of G WTP \& I WTP.

산량 증가분 $(80 \%)$ 보다 설비 증가분 $(100 \%)$ 이 더 커, $\mathrm{UV}$ 조사 량이 현재 대비 약 $20 \%$ 증가하여 $\mathrm{H}_{2} \mathrm{O}_{2}$ 주입률은 감소할 수 있을 것으로 예상된다.

용수생산량 및 원수 2-MIB 농도별 $\mathrm{UV} / \mathrm{H}_{2} \mathrm{O}_{2}$ 운영 원단위를 Fig. 19에 나타내었다. 원수 2-MIB $300 \mathrm{ng} / \mathrm{L}$ 유입 시 운영비 원단위(전력비 $+\mathrm{H}_{2} \mathrm{O}_{2}$ 구매비)는 용수생산량에 따라 25 48 원 $/ \mathrm{m}^{3}$ 으로 산정되었다. 용수생산량 증가로 UV 접촉시간이 짧 아져, $\mathrm{H}_{2} \mathrm{O}_{2}$ 의 주입률이 상승하여 운영 원단위가 증가하는 것 으로 판단된다. 다만, 장래분 도입 시 UV 조사량이 증가함에 따라 $\mathrm{H}_{2} \mathrm{O}_{2}$ 주입률은 감소하여 원단위 절감을 기대할 수 있다. 또한, I정수장 2단계 고도정수처리 설비 도입이 완료된 후에 도 용수생산량이 현재 수준( $150,000 \mathrm{~m}^{3} /$ 일 $)$ 을 유지할 경우, $\mathrm{UV}$ 설비는 $100 \%$ (UV reactor 4 기 운영) 가동하여 UV 조사량 을 증가시킴으로써 $\mathrm{H}_{2} \mathrm{O}_{2}$ 주입률을 감소시켜 운영하는 것이 더 경제적일 것으로 예상된다(Fig. 20).

\subsection{G정수장|정수장 연계운영을 통한 용수생산량 배분 방안 검토}

$\mathrm{UV} / \mathrm{H}_{2} \mathrm{O}_{2}$ 의 운영비 원단위는 Post Peroxone의 4 22배에 이 른다. G정수장과 I정수장 송수관로에는 연계운영을 위한 배관 이 설치되어 있어 있으며, 각 정수장 송수펌프의 양정 고려 시 $(\mathrm{G}$ 정수장 $110 \mathrm{~m} \times 4$ 대, $80 \mathrm{~m} \times 4$ 대, $\mathrm{I}$ 정수장 $49 \mathrm{~m} \times 3$ 대, $53 \mathrm{~m} \times 6$
대, $115 \mathrm{~m} \times 2$ 대) 각 정수장별 용수생산량의 배분이 가능하다. 이에 따라, 고농도 2-MIB 발생 시 G정수장의 용수생산량을 증가시켜 I정수장의 공급지역으로 공급하는 방안을 검토할 필요가 있다.

Fig.21에 정수장별 용수생산량 배분량에 따른 원단위 분석 결과를 나타내었다. 2 개 정수장 모두 장래분 도입이 완료되었 을 때의 시설용량을 기준으로 하였다. 2 개 정수장의 합산 용수 생산량은 400,000 600,000 m³일, 각 정수장별 이용률은 $\mathrm{G}$ 정 수장 $120 \%$ 이하, I정수장 $40 \%$ 이상을 적용하였으며, 원수 2-MIB $200 \mathrm{ng} / \mathrm{L}$, 정수 목표 2-MIB $8 \mathrm{ng} / \mathrm{L}$ 일로 설정하였다. 동절기 고농도 2-MIB가 발생할 경우, 원수의 탁도는 $5 \mathrm{NTU}$ 내외 수준으로 $\mathrm{G}$ 정수장의 이용률을 증가시켜도 표준 처리 공정 중 혼화-응집-침전 운영에는 문제가 없을 것으로 판단된 다. 또한 동절기 저수온, 고 $\mathrm{pH}$ 로 인해 $\mathrm{CT}$ 요구값이 상승하여 불활성화비가 감소할 수 있지만 $\mathrm{G}$ 정수장은 오존 소독을 병행 하기 때문에 안정적인 소독능 확보도 가능할 것으로 예상된 다. 다만, 여과공정의 경우 여과속도의 증가로 여과지속시간 이 단축되어 역세척 주기는 빨라질 수 있다.

용수생산량이 동일할 때, $\mathrm{G}$ 정수장의 용수생산비율을 높여 서 대응할 경우 $\mathrm{G}$ 정수장의 원단위 상승비용보다 I정수장의 원단위 감소비용이 더 크기 때문에 합산 원단위가 감소함을 확인할 수 있었다. 
I정수장의 용수생산량을 감소시킬 경우, UV 접촉시간이 길 어져 UV 조사량이 증가하기 때문에 $\mathrm{H}_{2} \mathrm{O}_{2}$ 주입률이 감소하기 때문이다. 따라서 장래 고농도의 2-MIB가 유입될 경우 G정수 장의 시설 부하를 고려하여 용수생산량을 증대시키고 연계운 영을 통해 I정수장 급수지역으로 용수를 공급하는 것이 경제 적으로 더 유리할 것으로 예측된다. 그러나 $\mathrm{G}$ 정수장의 이용률 을 높여서 운영하는 방식은 $\mathrm{G}$ 정수장 공정 운영 및 설비에 부하를 유발할 수 있으므로, 장기적으로는 UV 설비의 출력을 증대시키거나, $\mathrm{H}_{2} \mathrm{O}_{2}$ 의 사용량이 상대적으로 적은 중압램프로 의 전환, Pre Peroxone 추가 도입 등을 검토할 필요가 있다.

\section{4. 결론}

한강수계의 동일한 취수장에서 원수를 취수하는 경기도 고양 시 소재 G정수장(Post Peroxone $+\mathrm{GAC})$ 및 I정수장 $\left(\mathrm{UV} / \mathrm{H}_{2} \mathrm{O}_{2}+\right.$ $\mathrm{GAC} \mathrm{F} / \mathrm{A}$ )의 고농도 2-MIB 대응 결과를 통하여 각 정수장의 산화공정별 2-MIB 제거 특성을 비교 분석하고 최적 운영 방안 을 도출한 본 연구의 결론은 다음과 같다.

1) 정수장별 2-MIB 제거율은 G정수장(Post Peroxone+GAC) $70 \sim 100 \%$, I정수장 $\left(\mathrm{UV} / \mathrm{H}_{2} \mathrm{O}_{2}+\mathrm{GAC} \mathrm{F} / \mathrm{A}\right) \quad 50 \sim 96 \%$ 로, 먹는물 감시항목 기준 $(20 \mathrm{ng} / \mathrm{L}$ 이하)을 상시 만족할 수 있었다. 2017 년 2-MIB 유입 초기에 고도처리 공정 운영 결정을 위해 분석한 공정별 2-MIB 제거율(前공정 대비)은 G정수장 Post Peroxone $45 \sim 100 \%$, GAC $14 \sim 58 \%$, I정수장 $\mathrm{UV} / \mathrm{H}_{2} \mathrm{O}_{2} 67 \sim 85 \%$, GAC F/A $20 \sim 50 \%$ 로 나타났다. 2-MIB 제거율은 $\mathrm{AOP}$ 운영 조건에 영향 을 받음을 확인할 수 있었다.

2) 2-MIB 제거에 영향을 미치는 운영 조건은 $\mathrm{G}$ 정수장의 Post Peroxone은 $\left[\mathrm{O}_{3}\right.$ 주입률 $\times$ 접촉시간 $]$ 과 $\mathrm{H}_{2} \mathrm{O}_{2} / \mathrm{O}_{3}$ 이었으며, I정수장의 $\mathrm{UV} / \mathrm{H}_{2} \mathrm{O}_{2}$ 는 [UV 조사량 $\times \mathrm{H}_{2} \mathrm{O}_{2}$ 주입률]로 확인되 었다. 각 정수장의 운영 조건과 2-MIB 제거율을 통해 원수 2-MIB 농도 및 용수생산량에 따른 적정 약품 주입률 산정식을 도출할 수 있었다.

3) 2-MIB 대응에 따른 각 정수장의 운영비(전력비+약품비) 원단위를 비교한 결과, $\mathrm{I}$ 정수장이 $\mathrm{G}$ 정수장보다 6.6 24.3 원 $/ \mathrm{m}^{3}$ 더 높았다. 이는 $\mathrm{UV} / \mathrm{H}_{2} \mathrm{O}_{2}$ 의 과산화수소 주입률이 Post Peroxone 대비 11 43배로 높았기 때문인 것으로 사료된다.

4) 각 정수장 산화 설비의 성능평가 결과 및 약품 주입률 산정식을 통해 최적 운영 조건을 도출할 수 있었다. $\mathrm{G}$ 정수장 $\mathrm{O}_{3}$ 발생기의 경제적 운영을 위한 오존 발생농도는 $9 \%$ 였으며, $\mathrm{O}_{3}$ 주입률은 원수 2-MIB 농도와 용수생산량에 따라 $0.11 \sim 2.18$ $\mathrm{mg} / \mathrm{L}, \mathrm{H}_{2} \mathrm{O}_{2}$ 주입률은 $\mathrm{O}_{3}$ 의 $40 \%$ 로 도출되었다. I정수장 $\mathrm{UV} / \mathrm{H}_{2} \mathrm{O}_{2}$ 설비의 경제적 운영을 위한 $\mathrm{UV}$ 출력은 $100 \%$ 였으 며, $\mathrm{H}_{2} \mathrm{O}_{2}$ 주입률은 원수 2-MIB 농도와 용수생산량에 따라 $3 \sim 26 \mathrm{mg} / \mathrm{L}$ 로 도출되었다. I정수장 2 단계 설비 도입 완료 시, 용수생산량이 현재 수준 $\left(150,000 \mathrm{~m}^{3} /\right.$ 일 $)$ 일 경우에도 UV 설비 는 $100 \%$ (UV reactor 4 기 가동) 수준으로 운영하면 전력비는 상승하나 UV 조사량 증가에 따라 $\mathrm{H}_{2} \mathrm{O}_{2}$ 주입률이 감소하므로
더 경제적인 운영이 가능한 것으로 판단된다.

5) G정수장과 I정수장 송수관로에는 연계운영을 위한 배관 이 설치되어 있어 각 정수장별 용수생산량의 배분이 가능하 다. 용수생산량이 동일할 때, G정수장의 용수생산비율을 높여 서 대응할 경우 $\mathrm{G}$ 정수장의 원단위 상승비용보다 I정수장의 원단위 감소비용이 더 크기 때문에 합산 원단위가 감소함을 확인할 수 있었다. 다만 이 경우, G정수장 공정 운영 및 설비에 부하를 유발할 수 있으므로, 장기적으로는 UV 설비의 출력을 증대시키거나, $\mathrm{H}_{2} \mathrm{O}_{2}$ 의 사용량이 상대적으로 적은 중압램프로 의 전환, Pre Peroxone 추가 도입 등을 검토할 필요가 있다.

\section{References}

1. D. H. Rhew, K. A. You, M. S. Byeon, S. J. Youn, S. J. Hwang, Growth characteristics of blue-green algae (Anabaena spiroides) causing tastes and odors in the North-Han River, Korea, Korean J. Ecol. Environ., 46, 135-144(2013).

2. National Institute of Environmental Research, Physiological and Ecological Characteristics of Algae in the Lake Paldang(I), National Institute of Environmental Research, 62(2014).

3. H. G. Peterson, S. E. Hrudey, I. A. Cantin, T. R. Perley, S. L. Kenefick, Physiological toxicity, cell membrane damage and the release of dissolved organic carbon and geosmin by Aphanizomenon flos-aquae after exposure to water treatment chemicals, Water Res., 29(6), 1515-1523(1995).

4. N. Sugiura, O. Nishimura, Y. Inamor, T. Ouchiyama, R. Sudo, Grazing characteristics of musty-odor-compoundproducing Phormidium tenue by a microflagellate, Monas guttula, Water Res., 31(11), 2792-2796(1997).

5. G. Izaguirre, W. D. Taylor, A pseudanabaena species from Castaic Lake, California, that produces 2-methylisoborneol, Water Res., 32(5), 1673-1677(1998).

6. N. Sugiura, K. Nakano, Causative microorganisms for musty odor occurrence in the eutrophic Lake Kasumigaura, Hydrobiologia, 434, 145-150(2000).

7. I. M. K. Saadoun, K. K. Schrader, W. T. Blevins, Environmental and nutritional factors affecting geosmin synthesis by Anabaena sp., Water Res., 35(5), 1209-1218(2001).

8. P. V. Zimba, C. C. Grimm, C. P. Dionigi, C. R. Weirich, Phytoplankton community structure, biomass, and off-flavor: pond size relationships in Louisiana catfish ponds, J. World Aquacult. Soc., 32(1), 96-104(2001).

9. H. W. Paerl, D. F. Millie, Physiological ecology of toxic aquatic cyanobacteria, Phycologia, 35(6), 160-167(1996).

10. S. Nakayama, K. Esaki, K. Namba, Y. Taniguchi, N. Tabata, Improved ozonation in aqueous systems, Ozone Sci. Eng., 1(2), 119-131(1979).

11. D. W. Ferguson, M. J. Mcguire, B. Kochi, R. L. Wolfe, E. M. Aieta, Comparing peroxone and ozone for dontrolling taste and odor compounds, disinfection by products, and microorganisms, J. AWWA, 82(4), 181-191(1990). 
12. H. J. Lee, H. J. Son, J. S. Roh, S. W. Lee, K. W. Ji, P. J. Yoo, L. S. Kang, Oxidation of geosmin and 2-MIB in water using $\mathrm{O}_{3} / \mathrm{H}_{2} \mathrm{O}_{2}$ : kinetics evaluation, J. Korean Soc. Environ. Eng., 29(7), 826-832(2007).

13. J. H. Suh, M. Nohseni, A study on the relationship between biodegradability enhancement and oxidation of 1,4-dioxane using ozone and hydrogen peroxide, Water Res., 38(10), 2596-2604(2004).

14. C. Baus, M. Sona, H. J. Brauch, Ozonation and combined ozone $/ \mathrm{H}_{2} \mathrm{O}_{2}$, UV/Ozone and $\mathrm{UV} / \mathrm{H}_{2} \mathrm{O}_{2}$ for treatment of fuel oxygenates MTBE, ETBE, TAME and DIPE from water, in Proceedings of 4th IWA Oxidation Technology Conference for Water and Wastewater Treatment, Goslar, Germany(2006).

15. M. Kwon, S. Kim, Y. Ahn, Y. Jung, W. H. Joe, K. Lee, J. Kang, Remval of residual ozone in drinking water treatment using hydroxide and sodium thiosulfate, J. Korean Soc. Water Wastewater, 29(4), 481-491(2015).

16. J.-I. Park, Y. Lee, K.-A. Jang, T.-H. Kim, C. Park, J.-H. Yoo, A study in the optimization about Peroxone $\left(\mathrm{O}_{3} / \mathrm{H}_{2} \mathrm{O}_{2}\right.$-AOP)-quenching process in $\mathrm{G}$ water treatment plant for 2-MIB treatment and residual ozone removal, J. Korean Soc. Environ. Eng., 41(12), 703-715(2019).

17. USEPA, Long Term 2 Enhanced Surface Water Treatment Rule, USEPA(2006).

18. USEPA, Ultraviolet Disinfection Guidance Manual(UVDGM) for Final Long Term 2 Enhanced Surface Water Treatment Rule, USEPA(2006).

19. C. Lee, J. Yoon, U. V. Gunten, Oxidation degradation of $\mathrm{N}$-nitrosodimethylamine by conventional ozonation and the advanced oxidation process ozone/hydrogen peroxide, Water Res., 41(3), 581-590(2007).

20. W.-Y. Song, S.-W. Chang, Effective treatment of $\mathrm{N}$-nitorosodimethylamine using advanced oxidation process (UV process) and toxicity evaluation, J. Korean Soc. Water Qual., 25(1) 90-95(2009).

21. S.-H. Kim, L. J. Yoo, NDMA; new challenge, J. Korean Soc. Environ. Eng., 24(4), 743-746(2002).

22. J. Sohn, S. Park, E. Jung, Removal of taste and odor causing compounds in drinking water using pulse UV system, J. Korean Soc. Water Wastewater, 26(2), 219-228 (2012).

23. Y.-S. Ahn, D.-J. Yang, S.-H. Chae, J.-L. Lim, K.-H. Lee, Characteristics of disinfection and removal of 2-MIB using pulse UV lamp, J. Korean Soc. Water Wastewater, 23(1), 69-75(2009).

24. C. Park, S. Seo, I. Cho, Y. Jun, H. Ha, T.-M. Hwang, Degradation of residual pharmaceuticals in water by $\mathrm{UV} / \mathrm{H}_{2} \mathrm{O}_{2}$ advanced oxidation process, J. Korean Soc. Water Wastewater, 33(6), 469-480(2019).

25. K. Jang, C. Park, Y. Yi, J. Park, A comparative study on actual performances of the water treatment plant with $\mathrm{O}_{3}-\mathrm{AOP}+\mathrm{GAC}$ process and the other plant with UV-AOP+F/A process, KSWST Jour. Wat. Treat., 26(5), 129-141(2018).
26. L. Ho, J. P. Croue, G. Newcombe, The effect of water quality and NOM character on the ozonation of MIB and geosmin, Water Sci. Technol., 49(9), 249-255(2004).

27. S. Shin, J. Jung, A study on removal of geosmin and 2-MIB casing compounds by Peroxone/GAC process according to water temperature and $\mathrm{NaOH}$ concentration, KSWST Jour. Wat. Treat., 24(5), 153-163(2016).

28. J.-I. Park, Y. Lee, K.-H. Kim, T.-H. Lee, C.-J. Park, J.-H. Yoo, A prediction on the improvement of disinfection efficiency and optimal operation of residual chlorine on water distribution line by application of UV process in I WTP, J. Korean Soc. Environ. Eng., 41(11), 597-610(2019).

29. Y. Kim, Removal characteristics of geosmin by advanced water treatment process around the Han river water supply system, University of Seoul, 55-56(2014).

30. H. J. Son, S. J. Yoo, J. S. Roh, P. J. Yoo, Biological activated carbos (BAC) process in water treatment, J. Korean Soc. Environ, Eng., 31(4), 308-323(2009).

31. S. M. Korotta-Gamage, A. Sathasivan, A review: potential and challenges of biologically activated carbon to remove natural organic matter in drinking water purification process, Chemosphere, 167, 120-138(2017).

32. D.-M. Son, H.-J. Son, H.-J. Lee, L.-S. Kang, Removal of geosmin and 2-MIB using biological activated carbon process, J. Korean Soc. Water Wastewater, 23(2), 189-198 (2009).

33. H. J. Son, H. S. Yoon, J. H. Bin, Peroxone $\left(\mathrm{O}_{3} / \mathrm{H}_{2} \mathrm{O}_{2}\right)$ process in drinking water treatment, J. Korean Soc. Environ. Eng., 32(3), 296-308(2010).

\section{Authors}

\section{Jong-Il Park}

Korea Water Resources Corporation, Manager, ORCID (두 00000002-8549-9263

\section{Young Lee}

Korea Water Resources Corporation, Senior Manager

\section{Kyoung-A Jang}

Korea Water Resources Corporation, Senior Manager

\section{Keon-Hoi Kim}

Korea Water Resources Corporation, Manager

\section{Tae-Hoon Lee}

Korea Water Resources Corporation, Staff

\section{Sun-Wook Kim}

Korea Water Resources Corporation, Senior Manager 